Proceedings of the U.S. Geological Survey 2004 Mercury Workshop: Mercury Research and its Relation to Department of the Interior Resource Management

Open-File Report 2007-1026 



\section{Proceedings of the U.S. Geological Survey 2004 Mercury Workshop: Mercury Research and Its Relation to Department of the Interior Resource Management}

Edited by John A. Colman

Open-File Report 2007-1026 


\section{U.S. Department of the Interior DIRK KEMPTHORNE, Secretary}

\section{U.S. Geological Survey \\ Mark D. Myers, Director}

\section{U.S. Geological Survey, Reston, Virginia: 2007}

For product and ordering information:

World Wide Web: http://www.usgs.gov/pubprod

Telephone: 1-888-ASK-USGS

For more information on the USGS--the Federal source for science about the Earth, its natural and living resources, natural hazards, and the environment:

World Wide Web: http://www.usgs.gov

Telephone: 1-888-ASK-USGS

The abstracts in this volume that were written by U.S. Geological Survey authors were reviewed and approved for publication by the Survey. Abstracts submitted by researchers from academia and from state and other federal agencies are published as part of these proceedings, but do not necessarily reflect the Survey's policies and views.

Any use of trade, product, or firm names is for descriptive purposes only and does not imply endorsement by the U.S. Government.

Although this report is in the public domain, permission must be secured from the individual copyright owners to reproduce any copyrighted materials contained within this report.

Suggested citation:

Colman, J.A., editor, 2007, Proceedings of the U.S. Geological Survey 2004 Mercury Workshop: Mercury Research and Its Relation to Department of the Interior Resource Management: U.S. Geological Survery Open-File Report 2007$1026,25 \mathrm{p}$. 


\section{Executive Summary}

The Mercury Workshop was sponsored by the U.S. Geological Survey (USGS), Eastern Region, under the U.S. Department of Interior (DOI) Science on the DOI Landscape Initiative, on August 17-18, 2004, in Reston, Virginia. The workshop was convened to (1) summarize information on mercury sources and cycling on DOI lands in the eastern United States, (2) learn the perspectives of the DOI bureaus regarding mercury on DOI lands, (3) provide information to DOI land managers about monitoring mercury and minimizing mercury accumulation in wildlife and humans, and (4) consider future directions for mercury monitoring and research on DOI lands. This information was conveyed through invited oral presentations, a panel discussion by DOI bureau scientists, and contributed posters. These workshop proceedings present a summary of information on this complex subject, as well as a synopsis of concerns about mercury as expressed by researchers and land managers. All of the presentations were videotaped and are available at the following URL, along with the slides presented: $h t t p: / / w w w$. usgs.gov/mercury/2004workshop/

Presentations on the effects of mercury on humans and wildlife indicate the magnitude of the problem. An estimated 600,000 human newborns per year in the United States have levels of mercury in blood in excess of the U.S. Environmental Protection Agency reference dose, the amount estimated to be without an appreciable risk of deleterious effects. The effect on wildlife is equally compelling, likely contributing to population decreases of many threatened fish-eating species-including fish, birds, and mammals. Methylmercury is the major mercury chemical species affecting humans and wildlife; it is brought to higher predators, including people, through the aquatic food web and fish. Thus, mercury methylation rates in the environment and mercury deposition rates from the atmosphere are important factors in understanding the effects of mercury on humans and wildlife.

Most oral presentations at the workshop concerned investigations on DOI lands. These lands are widely distributed on the continent and offshore, and include most types of environments where biogeochemical processes generate methylmercury from mercury deposited from the atmosphere. The presentations indicated that land-management practices, such as burning, flooding, tilling or other ground disturbance, and fertilizing (including sulfur application), affect mercury cycling and the generation of methylmercury. The mechanisms for land-management effects likely involve alteration of surface-water $\mathrm{pH}$, sulfide and sulfate concentrations, and dissolved organic carbon concentrations, which have been determined in many of the studies to influence the generation of methylmercury and the accumulation of methylmercury in aquatic food webs.

The panel of DOI bureau scientists expressed concerns about mercury contamination in national parks and wildlife refuges, including effects on wildlife and sport fishing from atmospheric deposition of mercury that originates from emission sources off public lands. A need was expressed for site-specific instructions accessible to managers of the individual parks and refuges on monitoring and managing the mercury problem. Concerns on American Indian lands include the effects of mercury on human health from consumption of fish, which is a traditional food source among tribes in the Eastern Region of the USGS, and the effects on wildlife. For example, of the 180 pounds of fish consumed per adult per year that is traditional among the Minnesota Chippewa Tribe population, only 5 percent (9 pounds) can be consumed by women of child-bearing age or by children, if mercury consumption restrictions are followed. Concerns for offshore resources (marine environment) relate to basic mercury research questions. There is a need to define accurately the relative importance for mercury accumulation in the marine food web of various mercury sources, including sources associated with mineral exploration, fossil fuel combustion, and natural emissions from volcanoes. The source, whether anthropogenic or natural, of substantial amounts of mercury that can be found in marine fish is presently unknown. 
The concluding session of the workshop, with general discussion on future monitoring and research, pointed to the use of the location and environmental circumstance of public lands for establishing expanded monitoring of mercury deposition and mercury biogeochemical cycling investigations. National Park Service (NPS) and Fish and Wildlife Service (USFWS) officials expressed the need to package information in forms readily understood by land managers and by the public. Despite substantial progress in mercury research, significant questions remain. During the discussion, managers encouraged scientists to continue mercury research but also asked for interim products for use in land management, such as maps, databases, and site-specific recommendations that would lessen the effect of land-management practices on mercury accumulation.

The direction of future research, as indicated through the discussion, could include studies of the relation between mercury sources and mercury receptors. Progress has been made on the question of why adjacent lakes with presumably similar deposition rates of mercury from the atmosphere have substantially different concentrations of mercury in fish. In these lake systems, many environmental factors, such as $\mathrm{pH}$, dissolved organic carbon (DOC) concentration, sulfur compound concentration, proximity of wetlands, trophic state, and water clarity, mediate overall microbial methylmercury production (methylation and demethylation of mercury by bacteria). Variability among sites associated with these factors slows the progress of matching the proximity and size of mercury sources with effects at receptor sites, and makes forecasting the results of emission remediation uncertain. Monitoring ecosystems for changes in mercury occurrence and concentrations that result from decreases in mercury sources following remediation would help establish the relationship between source and receptor. A poster and several comments addressed strategies for establishing a network to monitor change.

Other research questions that relate to possible remediation strategies include the extent to which "old mercury" (previously deposited mercury) continues to be available for microbial methylmercury production. Understanding of the processes and controls of atmospheric deposition of mercury is incomplete in that known deposition rates from the Mercury Deposition Network cannot be simulated very closely with models of mercury deposition. Other uncertainties include determining the correct deposition rate (or atmospheric mercury residence time) resulting from the background global mercury pool, and determining whether the rate of background mercury deposition is sufficient to support substantial rates of methylation. Finally, there are many species that have not been evaluated with respect to mercury accumulation and effects. Wading birds, insectivorous birds, and other animals were mentioned in this regard during the discussion session.

Many questions for which there are answers in freshwater environments remain unanswered in marine environments. In the Gulf of Mexico, for example, the source of mercury in marine fish remains unknown. Is it of anthropogenic or natural origin? What is the relative importance of mercury from the Mississippi River compared to other sources? How do the very low concentrations of methylmercury in ocean water get concentrated to high levels in marine fish? What are the principal locations of mercury methylation in the marine system? How does mercury accumulation and elimination in marine fish compare to these processes in freshwater species? What are the relative amounts of methylmercury and total mercury in marine species? Answers to these and other questions about mercury in marine environments will require future research.

Environmental research on mercury has produced compelling evidence on the detrimental effects of mercury deposition from the atmosphere to the landscape. More investigations would be needed to determine how best to mitigate the effect of mercury already deposited on the landscape and to regulate mercury emissions to the atmosphere so that deposition will decrease to acceptable levels. 


\section{Contents}

Executive Summary .............................................................................................................................

Conversion Factors and Water-Quality Information .....................................................................vii

Abbreviations...................................................................................................................vii

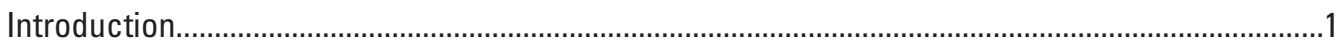

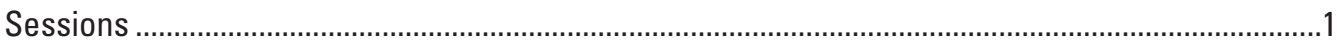

Session 1: Overview of Mercury Research and Relation to DOI Resource Management.......1

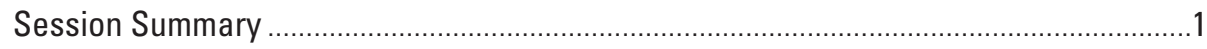

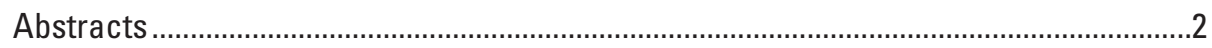

Overview of the Mercury Contamination Problem and the Remaining Gaps

in Understanding Related to Mercury Cycling and Fate in the

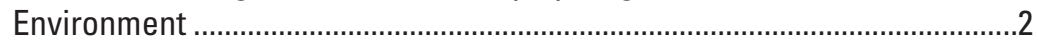

Update on USEPA's Regulatory Approach to Reducing Mercury Emissions............2

Panel presentation and discussion on DOI resource managers' perspectives

on mercury issues and needs for future research ..........................................

Session 2: Case Studies on DOI Lands and Effects of Land Management on Mercury ............3

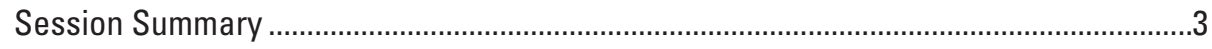

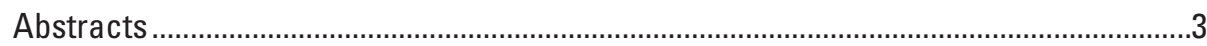

The Aquatic Cycling of Mercury in the Everglades (ACME) Project: Integrated Research Providing Information for Management and Science ...................3

Mercury in Wetlands on the Lostwood National Wildlife Refuge, North Dakota ....4

Mercury in Voyageurs National Park (Minnesota) Aquatic Food Chains .................4

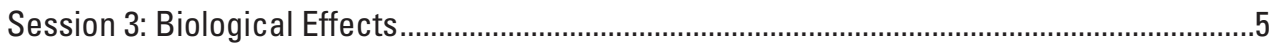

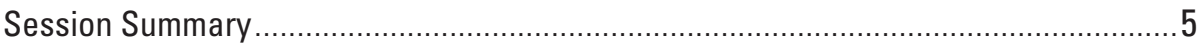

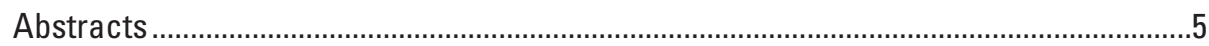

Target Species at Risk: Evidence of Endocrine Disruption and Reproductive Toxicity in Invertebrates, Fish, and Alligators...............................................5

Threshold Levels of Mercury in Bird Eggs: What We Know and Don't Know..........5

Human Health Effects ...............................................................................................6

Effect of Methylmercury Exposure on Reproductive Hormones of Male Northern Pike in Voyageurs National Park (Minnesota) ................................6

Exposure and Effects of Mercury on Terrestrial Wildlife............................................6

Session 4: Tools for Accessing Data, Models, and Ancillary Information .................................7

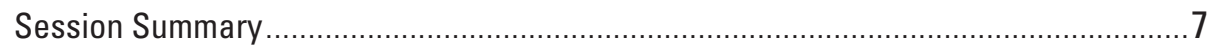

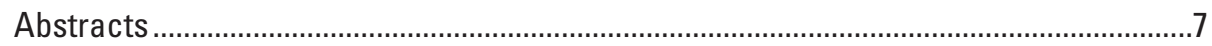

National Descriptive Model of Mercury in Fish Tissue ...........................................7

A Web-Based System for Environmental Mercury Mapping, Modeling, and Analysis ............................................................................................

The Mercury Deposition Network (MDN) - National Status and Trends ..................8

Trends and Uncertainties in Mercury Data Analysis: An Evaluation Using the Contaminant Exposure and Effects-Terrestrial Vertebrates (CEE-TV) Database ...........................................................................................

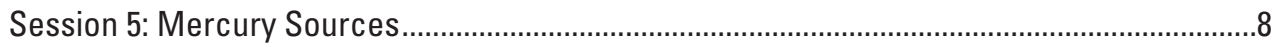

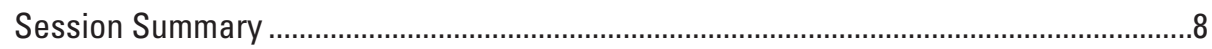

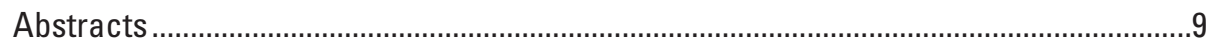


Use of Atmospheric Mercury Monitoring and Speciation in

Source-Receptor Investigations.

Non-Atmospheric Mercury Contamination and Bioaccumulation in

Mining-Impacted Watersheds

The Mercury Experiment to Assess Atmospheric Loadings in Canada and the U.S. (METAALICUS) Project. 10

Source-Apportionment for Atmospheric Mercury Deposition: Where Does The Mercury in Mercury Deposition Come From? .......................................10

References Cited ............................................................................................. 11

Atmospheric Chemistry and the Relative Importance of Emission Sources ..........11

Petroleum Drilling Fluids as a Source of Mercury to the Offshore Environment...11

Session 6: Influence of Ecosystem Setting on Mercury and Mercury Management .............12

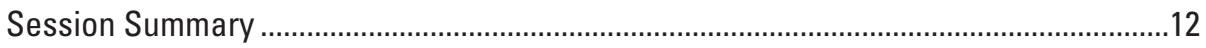

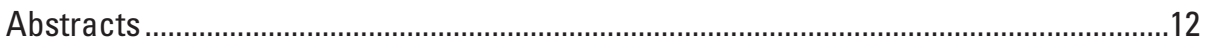

Mercury Bioaccumulation in Stream Ecosystems-Detailed Studies, Spatial Assessments, and Trend Monitoring...............................................12

Watershed Factors Influencing Bioaccumulation of Mercury ..................................13

Wetland Restoration and the Potential for Enhanced Mercury Methylation ..........13

Landscape Control on Mercury Biogeochemistry in Gauged Paired Watersheds at Acadia National Park

Session 7: Moderators' Summaries and Suggested Future Research Directions for the DOI Landscape Mercury Initiative....................................................................

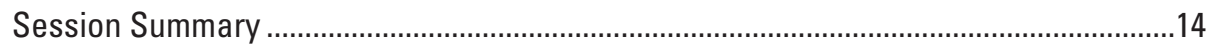

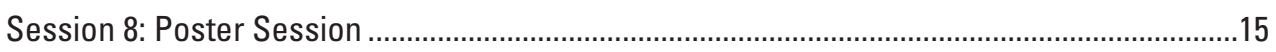

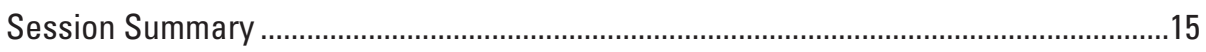

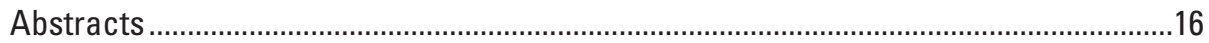

Aqueous Stability of Mercury on Fly Ash ..........................................................16

Mercury Burdens and Trophic Position of the Crayfish Orconectes virilis in Voyageurs National Park, Minnesota ............................................................16

Mercury in the Pacific Outer Continental Shelf.....................................................16

Designing a Mercury TMDL Study for the South River, Virginia..............................16

An Assessment of Risk of Methylmercury Exposure to Fish-Eating Birds Foraging at a Constructed Wetland in South Florida .................................17

Mercury Bioaccumulation in Lotic Salamanders: A Review and Assessment......17

Mercury Emissions and Lake Deposition: A Qualitative Model and Its Application to Lake Whatcom, Washington .................................................17

Mercury Deposition and Bioaccumulation Along an Urban Gradient in

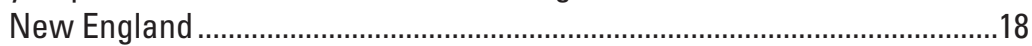

Mercury Exposure to Peregrine Falcons Nesting on Power Plant Stacks .............18

Modeling Uncertainty by Using Bayesian Networks for Mercury-Mitigation

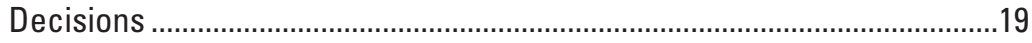

Mercury and Methylmercury Dynamics in Stream Water in Vermont, USA ..........19

Effects of Mercury Exposure on the Health and Fitness of Captive-Reared Common Loon (Gavia immer) Chicks ............................................................19

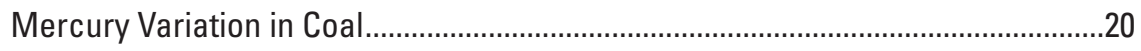

FDA's Initiative to Address the Public Health Policy on Mercury...........................20

Establishing a Network to Detect Trends in Mercury in Aquatic Ecosystems.......21 
The Usefulness of Chorioallantoic Membranes in Measuring Harmful

Levels of Mercury in Eggs ...

Egg Injections as a Means of Assessing the Embryotoxicity of

Methylmercury

Will Regulations That Are Adequate to Protect Wildlife from Mercury

Poisoning Also Provide Protection for Human Health?

How Embryotoxic Thresholds of Mercury Can Be Estimated from Mercury

Levels in Individual Eggs ..................................................................................23

Mercury Accumulation and Loss in Mallard Eggs .....................................................23

Enhancement of WARMF to Track Mercury Species in a River Basin from

Atmospheric Deposition to Fish Tissue .....................................................24

Distribution of Mercury in Shallow Ground Water of the New Jersey

Coastal Plain and a Possible Mechanism of Transport

\section{Conversion Factors and Water-Quality Information}

\begin{tabular}{|c|c|c|}
\hline Multiply & By & To obtain \\
\hline \multicolumn{3}{|c|}{ Length } \\
\hline inch (in.) & 2.54 & centimeter $(\mathrm{cm})$ \\
\hline foot $(\mathrm{ft})$ & 0.3048 & meter $(\mathrm{m})$ \\
\hline mile (mi) & 1.609 & kilometer $(\mathrm{km})$ \\
\hline \multicolumn{3}{|c|}{ Area } \\
\hline acre & 0.4047 & hectare (ha) \\
\hline square mile $\left(\mathrm{mi}^{2}\right)$ & 2.590 & square kilometer $\left(\mathrm{km}^{2}\right)$ \\
\hline \multicolumn{3}{|c|}{ Mass } \\
\hline pound, avoirdupois (lb) & 0.4536 & kilogram $(\mathrm{kg})$ \\
\hline \multicolumn{3}{|c|}{ Leakance } \\
\hline foot per day per foot $[(\mathrm{ft} / \mathrm{d}) / \mathrm{ft}]$ & 1 & meter per day per meter \\
\hline inch per year per foot $[(\mathrm{in} / \mathrm{yr}) / \mathrm{ft}]$ & 83.33 & $\begin{array}{l}\text { millimeter per year per meter } \\
{[(\mathrm{mm} / \mathrm{yr}) / \mathrm{m}]}\end{array}$ \\
\hline
\end{tabular}

Temperature in degrees Celsius $\left({ }^{\circ} \mathrm{C}\right)$ may be converted to degrees Fahrenheit $\left({ }^{\circ} \mathrm{F}\right)$ as follows:

${ }^{\circ} \mathrm{F}=\left(1.8 x^{\circ} \mathrm{C}\right)+32$

Temperature in degrees Fahrenheit $\left({ }^{\circ} \mathrm{F}\right)$ may be converted to degrees Celsius $\left({ }^{\circ} \mathrm{C}\right)$ as follows:

${ }^{\circ} \mathrm{C}=\left({ }^{\circ} \mathrm{F}-32\right) / 1.8$

Specific conductance is given in microsiemens per centimeter at 25 degrees Celsius $/ \mu \mathrm{S} / \mathrm{cm}$ at $\left.25^{\circ} \mathrm{C}\right)$.

Concentrations of chemical constituents in water are given either in milligrams per liter (mg/L), micrograms per liter $(\mu \mathrm{g} / \mathrm{L})$, nanograms per liter (ng/L), parts per million (ppm), or nanograms per gram $(\mathrm{ng} / \mathrm{g})$. 


\section{Abbreviations Used}

ACME - Aquatic Cycling of Mercury in the Everglades

CEE-TV - Contaminants Exposure and Effects Terrestrial Vertebrates Database

$\mathrm{Cl}-$ Chlorine

CUB - Coal utilization by-products

DHA - Docosahexaenic acid

DOC - Dissolved organic carbon

DOI - Department of the Interior

ELA - Experimental Lakes Area

EMMMA - Environmental Mercury Mapping, Modeling, \& Analysis database

FDA - Food and Drug Administration

$\mathrm{Hg}-$ Mercury

LNWR - Lostwood National Wildlife Refuge

LOAEL - Lowest observed adverse effect levels

MCL - Maximum contaminant level

MDN - Mercury Deposition Network

MeHg - Methylmercury

METAALICUS - Mercury Experiment to Assess Atmospheric Loadings in Canada and the U.S.

NDDH - North Dakota Department of Health

NPS - National Park Service

OCS - Outer Continental Shelf

$\mathrm{THg}$ - Total mercury

TMDL - Total maximum daily load

TOC - Total organic carbon

USEPA - United States Environmental Protection Agency

USFWS - United States Fish and Wildlife Service

USGS - U.S. Geological Survey

VNP - Voyageurs National Park

WAMT - Wisconsin Air Monitoring Trailer

WARMF - A GIS-based watershed model

ww - Wet weight 


\title{
Proceedings of the U.S. Geological Survey 2004 Mercury Workshop: Mercury Research and Its Relation to Department of the Interior Resource Management
}

\author{
Edited by John A. Colman
}

\section{Introduction}

As part of the Department of the Interior (DOI) program Science on the DOI Landscape Initiative, the U.S. Geological Survey (USGS), Eastern Region, held a workshop during August 17-18, 2004, in Reston, VA, on mercury in the environment as it relates to DOI resource management. DOI bureaus manage millions of acres of land and offshore resources subject to mercury deposition and to the effects of mercury on ecosystems and human health. The goals of the workshop were to (1) summarize information on mercury sources and cycling on DOI lands in the eastern United States, (2) learn the perspectives of the DOI bureaus regarding mercury on DOI lands, (3) provide information to DOI land managers about monitoring mercury and minimizing mercury accumulation in wildlife and humans, and (4) consider future directions for mercury monitoring and research on DOI lands.

The workshop focused on mercury research as it relates to DOI resource-management issues primarily in the eastern part of the United States (east of the Mississippi River). Topics included the influence of ecosystem setting on mercury biogeochemical transformation, land- and air-management practices as they affect mercury in the environment, mercury source issues, and effects of mercury on humans and wildlife. Mercury research topics were addressed by 24 invited oral presentations and 30 contributed posters. The perspectives of the DOI bureaus and land managers were addressed through a panel of scientists from the DOI resource-management bureaus and a Chippewa Indian Tribe of Minnesota. Discussion at the conclusion of the workshop was directed toward goals and long-term strategies for mercury research that will benefit DOI resource management. The panel, presentations, and discussions were videotaped and are available at the following URL, along with the slides presented:

http://www.usgs.gov/mercury/2004workshop/

Abstracts from the presentations and posters are included in this report, together with summaries of each presentation session.

The abstracts in this volume that were written by

U.S. Geological Survey authors were reviewed and approved for publication by the Survey. Abstracts submitted by researchers from academia and from state and other federal agencies are published as part of these proceedings, but do not necessarily reflect the Survey's policies and views. The use of trade, product, or firm names is for descriptive purposes only and does not imply endorsement by the U.S. Government.

\section{Sessions}

\section{Session 1: Overview of Mercury Research and Relation to DOI Resource Management}

Moderator: Eric Evenson, U.S. Geological Survey

\section{Session Summary}

Session 1 began with an overview of current knowledge and knowledge gaps on environmental effects of mercury from atmospheric sources. The session then moved to a discussion of government perspectives on the use of mercury research. Government perspectives were presented first from the regulatory point of view by the U.S. Environmental Protection Agency (USEPA), and then from four DOI bureaus and a representative of the Chippewa Indian Tribe in Minnesota. These perspectives set the focus for the presentations of the technical sessions that followed.

The first presentation for the session indicated that problems of mercury accumulation in freshwater ecosystems are becoming well documented, and many mechanisms of mercury transport and transformation are understood. Modeling and documenting the relation between emission sources of mercury and receptors continues to be an area of research. The next big task is designing regulations that best address remediation of the mercury accumulation problem.

The USEPA presentation described decreases in mercury emissions from two large regulated categories-municipal and medical-waste incinerators. Several scenarios also were 
described for potential additional decreases in mercury emissions as the result of proposed regulations on power plants that stem from the authority of the amended Clean Air Act in 1990. Regulations that would result in decreases in emissions from power plants are proposed for future dates, 2008 or later.

During the panel presentations, the science representatives of the land-management bureaus stressed the very large numbers of acres managed-100 million acres by the U.S. Fish and Wildlife Service and 1.76 billion offshore acres by the Minerals Management Service_or the number of land units managed - 388 parks — by the National Park Service. Clearly, many decisions are made by the managers of the refuge, park, or offshore acres that can affect the way mercury moves through the ecosystem. The task of managing mercury brings out many communication problems among scientists, managers, and the public that are common when dealing with a complex environmental process that has far-reaching cost and human and ecological effects in the balance. The managers have competing demands on their time and need to have options clearly defined and made specific to the managed site in order to act. Public lands provide a useful resource for scientists to investigate, with opportunity for contrasting environments, sensitive ecosystems, and long-term data sets. There is a continuing need for scientific investigation, but also a need for usable interim products for land managers and the public. The need and opportunity for public education with respect to mercury on public lands was mentioned by all bureau scientists.

A description of the effect of mercury on public lands was provided by the representative from the Chippewa Indian Tribe in Minnesota. During the question and answer period, he indicated that, if mercury-consumption regulations are followed, women of child-bearing age and children can eat only 5 percent of the 180 pounds of fish that are traditionally consumed per adult per year.

\section{Abstracts}

\section{Overview of the Mercury Contamination Problem and the Remaining Gaps in Understanding Related to Mercury Cycling and Fate in the Environment}

\section{By David P. Krabbenhoft ${ }^{1}$}

${ }^{1}$ U.S. Geological Survey, Middleton, WI (dpkrabbe@usgs.gov)

The potential consequences of mercury contamination of aquatic food webs were first recognized in the 1950s and 1960s in Minamata and Niigata, Japan, where human consumers of contaminated fish were severely poisoned. These and other tragic incidents prompted widespread reductions in direct releases of mercury into surface waters in many countries. Mercury levels in fish from affected waters typically declined during the years after point-source loads declined, leading to a widespread perception that the "mercury problem" had been solved. Since about 1985, however, widespread mercury contamination of aquatic biota has become evident in systems remote from obvious anthropogenic mercury sources. Investigations at these sites have shown that in most cases, atmospheric transport and low rates of mercury deposition are largely responsible for the observed widespread mercury contamination of aquatic ecosystems across the globe. In some cases, concentrations in fishes from these remote sites have equaled or exceeded those in fishes from waters that have been heavily contaminated by direct industrial discharges. Today, we seek to understand what ecological indicators are useful for predicting where problem areas are likely to occur. Mercury concentrations in fish are often elevated, for example, in fish from low-alkalinity or humic freshwaters, newly flooded reservoirs, and surface waters that adjoin wetlands. However, we lack sufficient information to predict reliably which aquatic ecosystems will contain mercury-contaminated biota.

Mercury cycling in the environment is extremely complex. Unlike most contaminants, some natural processes in the environment actually increase mercury toxicity by the conversion of inorganic mercury, which is the dominant form in deposition, to methylmercury, which is the dominant form in fish ( $>95$ percent). Although methylmercury comprises nearly all the mercury found in the top levels of aquatic food webs, it rarely exceeds 10 percent of the total mass of mercury in sediment or water. Gaps in our understanding of the processes and factors controlling exposure to methylmercury (methylation, demethylation, and biotic uptake) are key challenges facing scientists investigating the mercury problem. Several information gaps currently exist in the environmental mercury science basis, including: (1) availability of reliable, multimedia (biota, sediment, and water) mercury data from diverse ecosystem settings, including methylmercury determinations; (2) knowledge of the relative importance of factors controlling mercury methylation and bioaccumulation (mercury loading rates, mercury source type, ecosystem setting, and water and sediment chemistry); (3) a better understanding of the toxicological significance of methylmercury exposure on wildlife, and (4) current challenges on how to integrate the state of scientific understanding into policy considerations of lawmakers.

This presentation will focus on recent findings from several research projects that the USGS is involved with in the Everglades of Florida, the Experimental Lakes Area of Canada, and elsewhere. Findings related to recently discovered phenomenon, such as the new mercury versus old mercury reactivity in the environment will be discussed, and its ramifications for improvements in environmental contamination levels.

\section{Update on USEPA's Regulatory Approach to Reducing Mercury Emissions \\ By Ellen Brown ${ }^{1}$}

${ }^{1}$ U.S. Environmental Protection Agency, Washington DC

No abstract or presentation is online. 
Panel presentation and discussion on $\mathrm{DOI}$ resource managers' perspectives on mercury issues and needs for future research Panel members: Dan Ashe ${ }^{1}$, John Dennis², Jim Kendall ${ }^{3}$, Chip Groat ${ }^{4}$,
and John Persell

${ }^{1}$ Fish and Wildlife Service, Washington DC

${ }^{2}$ National Park Service, Washington, DC

${ }^{3}$ Minerals Management Service, Reston, VA

${ }^{4}$ U.S. Geological Survey, Reston, VA

${ }^{5}$ Chippewa Tribe, Cass Lake, MN

No abstract, presentations, or discussions are online.

\section{Session 2: Case Studies on DOI Lands and Effects of Land Management on Mercury}

Moderator: Neil Burgess, Environment Canada

\section{Session Summary}

Session 2 consisted of three case studies that described the mercury research methods currently in use and demonstrated the magnitude of the mercury problem on diverse eastern DOI lands-from the Everglades in the south coastal region to the Lost Woods Wildlife Refuge and the Voyageurs National Park in the northern continental region. Methods for quantifying the mercury problem were described, as well as experimental designs and results for assessing the factors that influence mercury accumulation in wildlife-primarily fish-in these studies. Atmospheric mercury deposition affects these three locations to different degrees because of possible different deposition rates and different factors that affect net methylation rates of the deposited mercury-presence of reducing environments where sulfate reducing bacteria can grow, sulfur concentrations and chemical forms of sulfur, dissolved organic carbon concentrations, position of wetlands in the drainage basin, and $\mathrm{pH}$. To some degree, these factors are a result of, or can be manipulated by, land management: sulfur is used in some types of agriculture, dissolved organic carbon is associated with wetlands and land inundation, submerged soils have anoxic conditions, and acidification is associated with fossil fuel combustion and the deposition of acid rain. The case studies indicate which combinations of factors have been shown to date to lead to the greatest net methylation rates.

\section{Abstracts}

The Aquatic Cycling of Mercury in the Everglades (ACME) Project: Integrated Research Providing Information for Management and Science

\author{
By William H. Orem ${ }^{1}$, David P. Krabbenhoft' ${ }^{2}$, Cynthia C. Gilmour ${ }^{3}$, and \\ George R. Aiken ${ }^{4}$ \\ 'USGS, Reston, VA (borem@usgs.gov) \\ ${ }^{2}$ USGS, Middleton, WI (dpkrabbe@usgs.gov) \\ ${ }^{3}$ Smithsonian Institution, Edgewater, MD (gilmourc@si.edu) \\ ${ }^{4}$ USGS, Boulder, CO (graiken@usgs.gov)
}

The Everglades are a series of sub-tropical freshwater wetlands extending about 200 miles north to south in south Florida, USA that encompass a World Heritage Site and International Biosphere Reserve. The Everglades were greatly altered by human activity beginning in the early 1900s, with the northern part of the ecosystem impacted by agricultural runoff, the entire system subjected to major alterations in its hydrologic regime, and recent acceleration in urbanization. Large portions of the Everglades are Federal lands, managed by the National Park Service (Everglades National Park and Big Cypress National Preserve) and the U.S. Fish and Wildlife Service (Arthur R. Marshall Loxahatchee National Wildlife Refuge). The protection of these Federal lands and restoration of the whole Everglades ecosystem is an important national priority. Restoration efforts funded by Federal, State, and private funds are currently underway, and include restoring natural sheet flow of water through removal of canal levees, and construction of buffer wetlands to improve water quality.

Among the principal issues facing restoration of the Everglades ecosystem is water quality. Mercury ( $\mathrm{Hg}$ ) represents one of the most important water-quality issues in the restoration of the Everglades, as well as being an important environmental issue throughout the USA and worldwide. The concentration of $\mathrm{Hg}$, specifically methylmercury $(\mathrm{MeHg})$, in biota is elevated throughout most of the Everglades, with levels of MeHg in Everglades' gamefish among the highest in the nation. The USGS began studies of $\mathrm{Hg}$ in the Everglades in the mid-1990s under the leadership of the Aquatic Cycling of Mercury in the Everglades (ACME) project. The objective of the ACME project was to determine the biogeochemical processes influencing the production and bioaccumulation of $\mathrm{MeHg}$ in the Everglades, thus, supporting restoration of the Everglades by providing land and water managers with information needed to minimize the impacts of $\mathrm{Hg}$ on the ecosystem. The transferability of $\mathrm{Hg}$ research conducted in the Everglades to other environments within the USA and worldwide was also an objective of this research.

Results from the ongoing ACME project show that the dominant source of $\mathrm{Hg}$ to the ecosystem is atmospheric deposition, while the major source of $\mathrm{MeHg}$ is new production in surface sediments. Bioaccumulation of $\mathrm{MeHg}$ occurs mainly via the benthic food web, with patterns of bioaccu- 
mulation driven by differences in $\mathrm{MeHg}$ production not by differences in bioaccumulation factors. ACME was also the first to document an ecosystem-scale sulfur gradient, with widespread sulfur contamination originating from the Everglades Agricultural Area. This sulfur contamination has a key effect on $\mathrm{MeHg}$ production in the Everglades by stimulating the metabolic activity of sulfate-reducing bacteria principally responsible for production of $\mathrm{MeHg}$ from inorganic $\mathrm{Hg}$. The influence of sulfur contamination on $\mathrm{MeHg}$ production is complex, however, because sulfate- reducing bacteria also produce sulfide, a reactive form of sulfur that has an opposite effect, inhibiting MeHg production. Sulfur availability and speciation, thus, result in a situation where maximum $\mathrm{MeHg}$ production occurs in a zone where sulfur levels are "just right" (Goldilocks Area), balancing sulfate stimulation and sulfide inhibition of $\mathrm{MeHg}$ production. Mesocosm experiments conducted by the ACME project have confirmed the importance of sulfur and atmospheric mercury in fueling the biomethylation of mercury in Everglades' sediments, and have also shown the importance of DOC in facilitating transport of $\mathrm{Hg}$ and $\mathrm{MeHg}$. ACME field and laboratory studies have further demonstrated that dry/wet cycles are important in stimulating $\mathrm{MeHg}$ production and bioaccumulation in the ecosystem. Issues for consideration by land and water managers involved in the Everglades restoration include reduction of the atmospheric $\mathrm{Hg}$ load to the ecosystem, reduction of sulfur loads, and how restoration plans that include changes in water flow through the marsh might affect sulfate movement and wetting/drying cycles. Each of these factors appears to have an important influence on the production and bioaccumulation of $\mathrm{MeHg}$ in the Everglades ecosystem.

\section{Mercury in Wetlands on the Lostwood National Wildlife Refuge, North Dakota}

\section{By Steven K. Sando ${ }^{1}$}

\section{${ }^{1}$ U.S. Geological Survey, Huron, SD (sksando@usgs.gov)}

The Lostwood National Wildlife Refuge (LNWR) encompasses 42 square miles in northwestern North Dakota and is formally designated as a Globally Important Bird Area. The refuge is located near the middle of the prairie pothole region, a large glaciated area in north-central North America that, on a mean annual basis, accounts for about 50 percent of continental migratory waterfowl production. The refuge has a very high density of depressional wetlands (an average of about 100 wetlands per square mile) that provide valuable wildlife habitat. Because of the complex hydrogeologic setting of the refuge and differences in inundation patterns among wetlands, water quality in the wetlands is highly variable.

During the past several years, the North Dakota Department of Health (NDDH), in cooperation with the U.S. Environmental Protection Agency (USEPA), has implemented programs to assess and protect the quality of North Dakota wetlands. Of particular concern with respect to LNWR wetlands are effects of methylmercury contamination. Wetlands are known to be active sites for mercury methylation, and
LNWR is close to several coal-combustion powerplants, which are major sources of atmospheric mercury. Thus, the NDDH and USEPA initiated a study to investigate the occurrence of mercury in LNWR and contacted the U.S. Geological Survey and U.S. Fish and Wildlife Service for assistance. The study is multifaceted and investigates mercury processes in several ecosystem components, including water, bed sediment, biota, and atmosphere. Preliminary results presented herein are limited to factors that affect mercury and methylmercury concentrations in water and bed sediments of LNWR wetlands.

In May 2003, water and bed-sediment samples were collected from 24 LNWR wetlands distributed among four wetland types (temporary, seasonal, semipermanent, and permanent). Samples were analyzed for properties and constituents most directly related to mercury chemistry in natural aquatic systems. Median methylmercury concentrations in water samples from nine seasonal and three semipermanent wetlands were greater than 1 nanogram per liter (ng/L). The largest methylmercury concentration $(9.56 \mathrm{ng} / \mathrm{L})$ was detected in a seasonal wetland. Methylmercury concentrations in water samples from six temporary and six permanent wetlands tended to be smaller than in the seasonal and semipermanent wetlands. Median methylmercury concentrations for the temporary and permanent wetlands were about 0.5 and $0.2 \mathrm{ng} / \mathrm{L}$, respectively.

Preliminary analyses indicate that methylmercury concentrations in LNWR wetlands are strongly affected by $\mathrm{pH}$, organic carbon, and sulfate in the water column. Seasonal and semipermanent wetlands that had methylmercury concentrations greater than $1 \mathrm{ng} / \mathrm{L}$ had $\mathrm{pH}$ values less than about 7.5 standard units, organic carbon concentrations greater than about 30 milligrams per liter (mg/L), and sulfate concentrations from about 10 to $100 \mathrm{mg} / \mathrm{L}$.

\section{Mercury in Voyageurs National Park (Minnesota) Aquatic Food Chains}

By J.D. Jeremiason', J.G. Wiener², B.C. Knights³, M.B. Sandheinrich², M.E. Brigham ${ }^{4}$, D.R. Engstrom ${ }^{5}$, L.G. Woodruff ${ }^{4}$, W.F. Cannon ${ }^{6}$, S.J. Balogh7, and K.R. Rolfhus ${ }^{2}$

\footnotetext{
${ }^{1}$ Gustavus Adolphus College, St. Peter, MN

${ }^{2}$ University of Wisconsin-La Crosse, La Crosse, WI

${ }^{3}$ U.S. Geological Survey, La Crosse, WI

${ }^{4}$ U.S. Geological Survey, Mounds View, MN

${ }^{5}$ St. Croix Watershed Research Station, MN

${ }^{6}$ U.S. Geological Survey, Reston, VA

${ }^{7}$ Metropolitan Council Environmental Services, St. Paul, MN
}

Methylmercury contamination of fish is a concern throughout Minnesota and elsewhere in the United States. The remote location of many national parks does not diminish their susceptibility to mercury pollution. In Minnesota, for example, the highest fish mercury levels are found in the remote lakes of Voyageurs National Park (VNP). Pregnant women and children are advised not to eat any fish in these lakes. Due to the high level of methylmercury bioaccumulation in the Park, 
the Minnesota Pollution Control Agency, the National Park Service, and the U.S. Geological Survey began a study in 2000 to identify causal factors leading to high mercury levels in aquatic biota of the VNP lakes.

Certain bacteria in lakes and wetlands transform inorganic divalent mercury into a more toxic form known as methylmercury - the form that accumulates in fish and biomagnifies in aquatic food webs. Fish become contaminated with methylmercury by eating food (plankton and smaller fish) that has absorbed methylmercury. As long as the fish continue to be exposed to methylmercury, concentrations continually build up in fish's bodies. Fish that eat other fish become even more highly contaminated. Thus, the fish most desired by many anglers-bass, walleye and northern pike-become the most affected, and larger fish tend to be the most contaminated.

High mercury levels in VNP were originally identified in a common top predator fish, northern pike, in several VNP lakes. Other VNP lakes, however, exhibited significantly lower levels of mercury in northern pike. Studies were designed to identify potential reasons for the elevated yet highly variable mercury levels found in VNP. Potential causal factors investigated include: (1) local sources of mercury deposition; (2) geologic mercury sources; (3) unique food web characteristics that enhance bioaccumulation in upper trophic levels; and (4) differences in mercury cycling including the formation of methylmercury.

The studies involved the collection of many environmental samples including: sediment cores to assess changes in mercury deposition over time and differences between lakes; soil cores to assess potential geologic sources; bioindicator fish (1-year-old yellow perch) and other aquatic organisms to assess differences in food-web contamination; and finally air and water samples to identify potential variation in the abundance of total mercury and methylmercury concentrations between lakes.

\section{Session 3: Biological Effects}

Moderator: Roger Hothem, U.S. Geological Survey

\section{Session Summary}

Session 3 described current research indicating that mercury is very toxic to humans and wildlife and that there is widespread exposure of humans and wildlife to mercury through aquatic food webs. Wildlife studies have included species that eat only fish and are therefore more affected by mercury than humans, who eat a mixture of food. Bird embryos are especially sensitive to mercury. Research was described that attempts to quantify bird-embryo sensitivity to mercury for a variety of avian species. Research also has shown that fish are not only a conduit for mercury transfer to higher-level predators but are also themselves affected through endocrine and reproductive disruption. In higher-level predators, neurological effects have been most studied, but recent research indicates that endocrine and reproductive effects are present as well. Recent research findings on human exposure indicate that fetal blood has greater concentrations of mercury than does maternal blood. The number of newborns per year in the United States with mercury concentrations in excess of the USEPA reference dose is 600,000 . This compares to the previous estimate of 300,000 that was based on concentrations in maternal blood.

\section{Abstracts}

Target Species at Risk: Evidence of Endocrine Disruption and Reproductive Toxicity in Invertebrates, Fish, and Alligators

By Tim Gross ${ }^{1}$

${ }^{1}$ U.S. Geological Survey, Gainesville, FL

The scheduled talk "Target Species at Risk" was cancelled.

Threshold Levels of Mercury in Bird Eggs: What We Know and Don't Know

By Gary H. Heinz' and David J. Hoffman²

${ }^{1}$ U.S. Geological Survey, Beltsville, MD (gary_heinz@usgs.gov
${ }^{2}$ U.S. Geological Survey, Beltsville, MD (david_hoffman@usgs.gov)

Why is it important to study the harmful effects of mercury in bird eggs? First, many species of birds, especially fisheating species, live in aquatic habitats that are contaminated by methylmercury. Second, females that ingest methylmercury pass this mercury on to their eggs. Third, avian embryos are among the most sensitive of all wildlife to methylmercury. Therefore, if the concentrations of mercury that harm the embryos of wild birds can be determined and if mercury regulations can be set to protect the embryos of the most sensitive wild birds, then it is likely that most other species of wildlife will be protected as well.

What is currently known about harmful thresholds of mercury in bird eggs has come mostly from research on domesticated strains of mallards (Anas platyrhynchos) and ring-necked pheasants (Phasianus colchicus). About 0.8 to $1.0 \mathrm{ppm}$ mercury, on a wet-weight basis, in mallard eggs is associated with embryotoxicity. For pheasants the harmful threshold in eggs is approximately 0.5 to $1.5 \mathrm{ppm}$. The lowest concentration of mercury, on a wet-weight basis, in the diet of breeding female birds that has caused reproductive impairment in controlled laboratory studies is about $0.1 \mathrm{ppm}$ for mallards. Interestingly, this dietary value of $0.1 \mathrm{ppm}$ mercury for mallards is lower than values (from 0.4 to $1.0 \mathrm{ppm} \mathrm{Hg}$ ) typically used as dietary guidelines to protect human health.

Unfortunately, what is not known for birds is the information that is most important to know: how much mercury must be in the diet and eggs of wild species for embryotoxicity to occur? Determining these embryotoxic thresholds for wild 
birds needs to be achieved using a combination of different approaches. One approach will be to conduct field studies to measure levels of mercury in eggs that are associated with embryo mortality. However, because there are so many other factors that can cause reproductive problems in nature, findings from the field will need to be corroborated by those from controlled feeding studies with wild species of birds. The number of these controlled feeding studies is going to be few, owing to the great expense and time required to establish breeding colonies of wild birds in captivity. Consequently, other approaches will need to be considered. The approach we used was to collect wild bird eggs from the field and inject them with known concentrations of methylmercury. Results from these egg injection studies showed that the embryos of some species of wild birds are more sensitive to injected methylmercury than are the embryos of mallards. Therefore, harmful thresholds of mercury established for mallard eggs may not be protective of some wild bird eggs.

\section{Human Health Effects}

Presenter: Kate Mahaffey, U.S. Environmental Protection Agency

No abstract or presentation is online.

\section{Effect of Methylmercury Exposure on Reproductive Hormones of Male Northern Pike in Voyageurs National Park (Minnesota)}

[Title in the agenda: Mercury as an Endocrine Disruptor in Fish] By M. Sandheinrich', P. Drevnick², J. Wiener ${ }^{1}$, B. Knights ${ }^{3}$, and J. Jeremiason ${ }^{4}$

${ }^{1}$ University of Wisconsin-La Crosse, La Crosse, WI

${ }^{2}$ Miami University, Oxford, OH (drevnipe@muohio.edu)

${ }^{3}$ U.S. Geological Survey, La Crosse, WI

${ }^{4}$ Minnesota Pollution Control Agency, St. Paul, MN

Recent laboratory experiments have demonstrated impaired reproduction and suppressed sex steroid concentrations in fish exposed to environmentally realistic concentrations of dietary methylmercury, but few studies have examined reproductive effects in wild fish. We quantified sex hormones in adult male northern pike (Esox lucius) from semi-pristine drainage lakes in Voyageurs National Park, MN. The lakes span a narrow range in $\mathrm{pH}$, but vary more than 10 -fold in methylmercury concentrations in resident northern pike, apparently due largely to differences in methylmercury supply from connected wetlands. Fish were sampled shortly before active spawning in early May 2002 and 2003. We quantified total mercury in axial muscle by CVAAS and testosterone and 11-ketotestosterone in plasma by ELISA. Concentrations of reproductive hormones varied greatly among individual fish within each lake. However, mean hormone concentrations decreased markedly with increasing methylmercury exposure among lakes, as reflected by the concentration of total mercury in axial muscle tissue of the fish. This suggests that dietary methylmercury suppressed reproductive hormones, an effect that could reduce reproductive success in wild populations of fish.

\section{Exposure and Effects of Mercury on Terrestrial Wildlife}

\author{
By David C. Evers'
}

${ }^{1}$ BioDiversity Research Institute, Gorham, ME

Developing exposure profiles for methylmercury availability is an important step to identify biological hotspots and to determine potential impacts on wildlife. The heterogeneous distribution of available methylmercury across a landscape requires background knowledge of mercury cycling and pharmacokinetics of species representing multiple taxa and foraging guilds. Determining the lowest observed adverse effect levels (LOAEL) for birds and mammals is necessary to place exposure levels into context. There are two major baseline foraging guilds of concern: fish and arthropods. Indicator species chosen to represent these foraging guilds for various habitats and geographic areas are part of a new national indicators program developed during a workshop sponsored by the USEPA.

Fish represent the traditional pathway of concern for biomagnification of methylmercury. One of the better indicators of the fish pathway is the common loon. The loon is a longlived, high-trophic level, obligate piscivore and has been well studied for mercury exposure and effects. Field efforts have developed a high resolution exposure profile in the northern United States and parts of Alaska and Canada. These same efforts have shown that (1) loon blood and egg mercury levels increase from western to eastern North America, (2) loon blood and egg mercury levels strongly correlate, and (3) loon blood and local prey mercury levels strongly correlate. Longterm studies in the Rangeley Lakes region in Maine and New Hampshire correlate behavioral, physiological, and reproductive impacts with methylmercury levels. Reproductive success for high-risk loon territories (those greater than 3.0 micrograms per gram wet weight ( $\mu \mathrm{g} / \mathrm{g} \mathrm{ww})$ ) showed 40 percent fewer fledged young than low-risk loon territories (those less than $1.0 \mu \mathrm{g} / \mathrm{g} \mathrm{ww})$. Developing population models indicate that approximately 18 percent of a loon population needs to exceed the LOAEL to produce a significant negative population trend. Because efforts to develop a wildlife criterion value for the common loon have been successful, an analysis of water and loon mercury levels in some states, such as Maine, indicates population level impacts from mercury on piscivorous birds exist.

In Maine, the belted kingfisher and bald eagle demonstrate an increasing trend of methylmercury availability in four major aquatic habitat types: lowest levels exist in marine areas, higher levels are in estuaries and rivers, and the highest levels are in lakes. Studies with the river otter and mink show similar patterns. In marine systems, appropriate near-shore indicators include the common tern, while offshore mercury levels can best be determined through the Leach's storm-petrel.

Recent findings indicate that both aquatic and terrestrial invertebrate foodwebs also have the ability to biomagnify methylmercury to levels that are considered harmful to 
wildlife. The aquatic-based feeding habitats of waterthrushes and dippers make these species prime indicators of riverine habitats. Because of the ease of sampling, tree swallows and bats are preferred indicators of many aquatic habitats including wetlands, although songbirds feeding on non-emerging insects, such as spiders and centipedes, are more likely at greater risk. Insectivores such as the Bicknell's and wood thrushes, Carolina wren, saltmarsh sharp-tailed and seaside sparrows, and rusty blackbird have known or suspected elevated mercury levels. Recent data demonstrate that blood mercury levels of some insectivores exceed associated piscivore mercury levels. Such compelling findings indicate further research is needed to better understand the exposure and effects of methylmercury availability within the invertebrate foodweb.

\section{Session 4: Tools for Accessing Data, Models, and Ancillary Information}

\author{
Moderator: Neil Kamman, Vermont Department of Environmental \\ Conservation
}

\section{Session Summary}

As a part of the maturing of the science and investigations of mercury, some tools (databases especially) are now available, accessible on the internet, for comparing mercury concentrations in biota and for assessing rates of atmospheric wet deposition in the United States. The presentations in Session 4 described some of these tools. These map-based data are especially useful for DOI land managers because they cover all or large parts of the country. The Environmental Mercury Mapping, Modeling, \& Analysis database (EMMMA) includes mercury concentrations from many fish databases and ways to compare concentrations between species and sizes of fish through a model of mercury accumulation in fish tissue. The model was also presented in the session. The Mercury Deposition Network (MDN) has wet-deposition mercury data from approximately 250 stations across the country. Data collected weekly from the sites, most located east of the Mississippi River, are available on the internet. Deposition rates vary by a factor of about 10, from a low in west-central Canada to a high in southern Florida. The Contaminants Exposure and Effects Terrestrial Vertebrates Database (CEE-TV) complements the EMMMA database by including terrestrial species. The CEE-TV database includes species that eat fish and that would be affected by mercury but is restricted to estuarine and coastal habitats along the Atlantic, Gulf and Pacific coasts, and in the Great Lakes region.

\section{Abstracts}

\section{National Descriptive Model of Mercury in Fish Tissue}

By Steve Wente ${ }^{1}$

\section{${ }^{1}$ U.S. Geological Survey, Mounds View, MN}

Many Federal, State, local and Tribal agencies monitor mercury in fish-tissue samples to identify sites with elevated fish tissue mercury (fish-mercury) concentrations, monitor fish-mercury concentrations over time, and produce fish consumption advisories. Interpretation of these monitoring data is impeded by difficulties in separating the effects of sample characteristics (species, tissue type, and length of fish) from the effects of environmental variations (spatial and temporal trends) in fish-mercury concentrations. Without such a separation, variation in fish-mercury concentrations due to differences in the characteristics of samples collected over time or across space can be misattributed to temporal or spatial trends. Conversely, actual trends in fish-mercury concentration can be misattributed to differences in sample characteristics. This presentation describes a statistical model and national data set $(45,605$ observations) for calibrating a statistical model that can distinguish and isolate spatiotemporal from sample characteristic effects in fish-mercury concentration data. This model can be used for evaluating spatial and temporal trends in fish-mercury concentrations and for developing fish consumption advisories. The observed fish-mercury concentration data and model predictions $\left(\mathrm{R}^{2}=0.82\right.$, prediction error $=38.2$ percent) can be accessed, displayed geospatially, and downloaded via the World Wide Web (http://emmma. usgs.gov). A report describing the model and national data set (http://pubs.water.usgs.gov/sir20045199/) is also available. This model and the associated website may assist in the interpretation of large amounts of data from widespread fish-mercury monitoring efforts.

\section{A Web-Based System for Environmental Mercury Mapping, Modeling, and Analysis}

[Title as in the agenda: Environmental Mercury Mapping, Modeling, and Analysis (EMMMA) - Web Deployment of the Wente Fish Tissue Mercury Model, Online Access to Mercury Data, and Integration with The National Map]

By Paul P. Hearn', David Donato', John Aguinaldo', and Steven P. Wente

\section{${ }^{1}$ U.S. Geological Survey, Reston, VA}

The U.S. Geological Survey (USGS) and the National Institute of Environmental Health Science have chosen mercury as a test contaminant to develop a prototype web-based system to support geospatial data analysis by environmental and health researchers, as well as land and resource managers. The Environmental Mercury Mapping, Modeling, and Analysis (EMMMA) website (http://emmma.usgs.gov) provides 1) easy access to environmental mercury data sets, 2) an online model for normalizing mercury in fish tissue, and 3) integrated 
USGS maps, imagery, geospatial tools, and other thematic data.

EMMMA's fish-tissue mercury model factors out variations in mercury due to differences in species, length, and sample type. Application of this model to a comprehensive national compilation of fish tissue data will allow spatial and temporal trends in mercury concentrations to be detected that would otherwise be obscured. Also, because fewer samples are needed to produce fish consumption advisories, analytical costs to states can be lowered substantially.

Principal data sets accessible through the EMMMA website include mercury concentrations in fish tissue, soils, stream sediments, and coal; data on atmospheric mercury emissions; locations of atmospheric mercury monitoring sites and related mercury deposition data; and locations of mercury mines and other ore deposits. EMMMA's map viewer allows thematic data to be displayed together with USGS topographic maps, aerial photographs, satellite imagery, land cover, and other data from USGS's The National Map. Data can be downloaded both as nationwide data sets and spatially discrete subsets selected using the map viewer.

\section{The Mercury Deposition Network (MDN) - National Status and Trends}

By Mark Nilles ${ }^{1}$

${ }^{1}$ U.S. Geological Survey, Lakewood, CO

No abstract or presentation is online.

Trends and Uncertainties in Mercury Data Analysis: An Evaluation Using the Contaminant Exposure and EffectsTerrestrial Vertebrates (CEE-TV) Database

\footnotetext{
By N. Golden', O. Allen', B. Rattner², K. Eisenreich², M. McKernan²

${ }^{1}$ U.S. Fish and Wildlife Service, Arlington, VA (Nancy_Golden@fws.gov)

${ }^{2}$ U.S. Geological Survey, Laurel, MD (Barnett_Rattner@usgs.gov)
}

The Contaminant Exposure and Effects-Terrestrial Vertebrates (CEE-TV) database summarizes ecotoxicological data for terrestrial vertebrates inhabiting estuarine and coastal habitat along the Atlantic, Gulf, and Pacific coasts, Alaska, Hawaii, and the Great Lakes. Data are compiled from a wide variety of both published and unpublished sources, including peer-reviewed journal articles, reports from conservation agencies, conference proceedings, necrospy results, and incident databases. The CEE-TV database is currently accessible online (www.pwrc.usgs.gov/contaminants-online) and can be searched by taxonomic, temporal, geographic, or chemical-specific query. Of 16,921 records currently in the database, 3,722 (22 percent) contain exposure data on mercury in amphibians, reptiles, birds, and mammals. Data are available for 222 species, with the majority describing mercury concentrations in tissues of birds (2,749 records), followed by mammals (744 records). Very little data are available to describe mercury exposure in reptiles and amphibians, consistent with the larger data gap for ecotoxicological information for these vertebrate classes. Data collected from 1960 to 1999 account for 97 percent of mercury records, although yearly updating of CEE-TV will increase the amount of current data.

The CEE-TV database contains mercury data for 17 endangered species, with concentrations in tissues of bald eagle (Haliaeetus leucocephalus), California least tern (Sterna antillarum browni), roseate tern (Sterna dougallii), wood stork (Mycteria americana), and Florida panther (Felis concolor coryi) exceeding thresholds associated with adverse effects. More than half of all mercury records contain information for fish-eating birds, with the herring gull (Larus argentatus), common loon (Gavia immer), and bald eagle accounting for more data than any other individual species. No temporal trends were found for mercury in eggs of fish-eating birds, although regional differences were identified. Mean concentrations in eggs collected from the Atlantic Coast $(0.60 \mu \mathrm{g} / \mathrm{g}$ wet weight) were higher than concentrations in eggs collected from the Pacific Coast $(0.38 \mu \mathrm{g} / \mathrm{g})$, Gulf Coast $(0.34 \mu \mathrm{g} / \mathrm{g})$, or the Great Lakes $(0.38 \mu \mathrm{g} / \mathrm{g})$. For fish-eating birds in Florida, mean concentrations in eggs were lower than these averages $(0.18 \mu \mathrm{g} / \mathrm{g}$ wet weight $)$, following the removal of one atypically high data point $(7.93 \mu \mathrm{g} / \mathrm{g}$ in sooty tern, (Sterna fuscata), eggs from the Dry Tortugas). However, a greater percentage (50 percent) of feathers collected from birds in Florida contained mercury concentrations at or above thresholds for adverse effects than all other states combined (15 percent above threshold value). Despite the discovery of these trends, disparate methods of collection, chemical analysis, and reporting for much of the CEE-TV data confound many temporal and geographic comparisons, and reveal the need for consistent and repeatable terrestrial vertebrate contaminant monitoring for the elucidation of data gaps and trends.

\section{Session 5: Mercury Sources}

Moderator: Lee Tarnay, National Park Service

\section{Session Summary}

This session focused primarily on sources of atmospheric mercury, although the effects of two important types of point sources_-mining and offshore drilling — also were described. Deposition of mercury from the atmosphere takes place throughout the United States and is sufficient in many locations to cause problematic concentrations of mercury in fish and fish-eating species. Point sources of mercury are important locally, but are likely not the primary focus of concern on DOI lands in the eastern United States, many of which are protected or removed from point sources. Drilling activities also are unlikely to be a primary focus of concern for DOI offshore resource managers, because the mercury contributions from drilling activities are small. Although mercury contamination through atmospheric deposition is known to be a problem, the details of contributions and speciation of mercury from various sources to the atmosphere, residence time of the various 
forms of mercury in the atmosphere, and variable reactivity on the ground from deposited forms are still not well understood. At present, model simulations of wet mercury deposition do not match measured deposition in some areas, such as the southeastern U.S. (measured greater than simulated) and the northeastern U.S. (measured less than simulated). The effects of proposed emission decreases on mercury incorporation into fish are also uncertain. A novel experiment of whole-ecosystem dosing with mercury, designed to investigate this question, was the subject of one of the presentations of the session. Initial results indicate that recently deposited mercury is more available to biota than historically deposited mercury. Thus, the effects of decreased emissions on biota may be realized relatively quickly following source reduction.

\section{Abstracts}

\section{Use of Atmospheric Mercury Monitoring and Speciation in Source-Receptor Investigations}

[Title in the agenda: Defining Atmospheric Mercury Source-Receptor Relations: The USGS Mobile Mercury Lab]

By Mark L. Olson', David P. Krabbenhoft² , John F. DeWild ${ }^{3}$, and Shane D. Olund ${ }^{4}$

${ }^{1}$ U.S. Geological Survey, Middleton, WI (mlolson@usgs.gov)

2U.S. Geological Survey, Middleton, WI (dpkrabbe@usgs.gov)

${ }_{3}^{3}$ U.S. Geological Survey, Middleton, WI (jfdewild@usgs.gov)

${ }^{4}$ U.S. Geological Survey, Middleton, WI (sdolund@usgs.gov)

Over the past 15-20 years, researchers have established that atmospheric mercury emissions from a wide variety of natural and human-related sources are largely responsible for widespread mercury contamination in aquatic ecosystems. Although the USGS has been a leader in studies of aquatic cycling and fate of mercury, the agency has not been an active participant in atmospheric mercury research. In 2003, with the assistance of the Toxics program, the Wisconsin District Mercury Laboratory assembled a platform-the Wisconsin Air Monitoring Trailer (WAMT) — upon which atmospheric mercury cycling studies can be conducted. The WAMT has the capability of producing real-time data for concentrations of elemental, reactive, and particulate mercury, plus oxides of nitrogen, sulfur dioxide, ozone, particulate matter, and meteorological data. Thus far, the WAMT has deployed at two sites in southern Colorado, Yellowstone Park, Lostwood National Wildlife Refuge in northwestern North Dakota, and twice in the St. Louis, Missouri, and Mount Horeb, Wisconsin, areas. Chemical and meteorological data are combined and plotted, typically on polar plots, to potentially identify mercury emission sources and provide data for ground-truthing mercury emission models.

\section{Non-Atmospheric Mercury Contamination and Bioaccumulation in Mining-Impacted Watersheds}

By C.N. Alpers ${ }^{1}$

\section{${ }^{1}$ U.S. Geological Survey, Sacramento, CA (cnalpers@usgs.gov)}

Mercury contamination of water, sediment, and biota has emerged as a significant environmental problem in watersheds affected by historical mining of mercury, gold, and silver. Elevated mercury concentrations are known to occur in some base-metal and coal deposits, but there is currently a lack of data on possible mercury contamination associated with these deposits. Although the environmental effects of mercury from historical mining are most evident in western states, a significant amount of historical mining took place in many midwestern and eastern states. Therefore, historical mine sites and downstream areas affected by mining are potential ongoing sources of mercury contamination in many watersheds throughout the country.

Historical mercury mining the U.S. was concentrated in several mining districts in the western states. Most domestic mercury production came from the mining and retorting of cinnabar ores in the Coast Range of California (1860s-1960s), whereas minor mercury production came from mining districts in Nevada, Oregon, Washington, southwestern Alaska, Arizona, western Texas, and Arkansas. Some of the mercury mining areas in California have been designated as federal or state Superfund sites because of associated mercury contamination and bioaccumulation, and others are under investigation for possible remediation.

Mercury amalgamation methods were used to enhance the recovery of gold and silver at numerous placer (unconsolidated gravel), saprolite (deeply weathered bedrock), and lode (hard-rock) mines throughout the U.S. Historical records of mining and associated mercury use indicate that large quantities of mercury were lost to the environment in association with historical mining and metal-recovery practices. Hydraulic mining methods developed in California during the 1850s used mercury to recover placer gold in sluice boxes and undercurrents. Mercury was also used to recover placer gold from dragline and bucket-line dredging operations. In California, it is estimated that about 10 million lb of mercury were lost to the environment at placer gold mines (1850s-1960s), and about 3 million lb of mercury were lost from stamp mills at lode gold mines (1880s-1930s). Mercury losses from stamp mills at silver mines in the Comstock Lode, Nevada, are estimated at 15 million lb (1860s-1890s). Based on total gold production, it is estimated that mercury losses in the southern Appalachian Mountains were about 0.4 million lb (1820s-1890s).

Resource managers should be aware that historical mining is likely to have left a legacy of mercury contamination at the local scale near abandoned gold, silver, and mercury mine sites. Base-metal and coal deposits may also have elevated mercury concentrations, so associated mine wastes and drainage should be evaluated for possible mercury contamination. The degree of mercury contamination associated with historical mining depends on the scale of mining, the mercury 
content of ores and mining wastes, and the extent of mercury use in precious metal extraction and ore beneficiation practices. Numerous environmental factors influence the methylation and bioaccumulation of mercury at local and regional scales, including temperature, $\mathrm{pH}$, oxidation-reduction, food web dynamics, and the abundance and speciation of mercury, sulfur, iron, and organic carbon.

\section{The Mercury Experiment to Assess Atmospheric Loadings in Canada and the U.S. (METAALICUS) Project}

\section{By D.P. Krabbenhoft ${ }^{1}$}

\section{${ }^{1}$ U.S. Geological Survey, Middleton, WI (dpkrabbe@usgs.gov)}

The Mercury Experiment to Assess Atmospheric Loadings in Canada and the U.S. (METAALICUS) project is a whole-ecosystem experiment specifically designed to examine the relation between atmospheric mercury deposition and fish mercury concentrations. The prompting to propose and conduct such a difficult scientific experiment comes from a lack of clear evidence whether a change atmospheric mercury deposition to an ecosystem will affect fish mercury, and at what time scales. This is important due to impending regulations to control mercury emissions from electric utilities in North America. To address this concern, a multi-national team of scientists was formed to devise a whole-ecosystem, mercury-dosing study, whereby mercury would be deliberately added to an entire watershed. The study is being conducted at the Experimental Lakes Area (ELA), which is located in northwestern Ontario, Canada. Large-scale manipulation studies have been conducted at the ELA for over thirty years, and it is one of the only places where such studies have been done. Whole-ecosystem manipulation studies have a distinct advantage over small-scale (lab scale) studies, in that all the ecosystem components, natural processes and complexities that are present in watersheds are accounted for. For example, by conducting this experiment at the watershed scale, METAALIUS biologists are able to study the response of an entire food web to a mercury dose.

The study watershed is 44 hectares, and contains upland forests, streams, a wetland, and a lake (Lake 658). One of the complicating factors in conducting a mercury addition project, is the fact that large inventories of relic mercury already exist in the watershed, and thus it would be potentially difficult to distinguish whether observed responses were truly due to the added mercury or the pre-existing mercury. To assess the response of the mercury added to the watershed, team scientists agreed to add the mercury in the form of three different stable isotopes of mercury, one each added to the three principal components of the watershed: uplands $\left({ }^{200} \mathrm{Hg}\right)$, wetland $\left({ }^{198} \mathrm{Hg}\right)$, and lake $\left.{ }^{(202} \mathrm{Hg}\right)$. By amending different isotope tracers to each watershed component, METAALICUS researchers can distinguish the relative importance of direct atmospheric deposition (simulated as mercury added directly to the lake) versus mercury derived from watershed runoff and that from exchange with the contiguous wetland. Mercury additions to the study watershed were initiated in 2001, and are scheduled to continue for six consecutive years if funding can be secured for the sixth year in 2006. Compared to the ambient wet mercury deposition rate of about 5-7 microgram per square meter per year $\left(\mu \mathrm{g} / \mathrm{m}^{2} / \mathrm{yr}\right)$, about $20-25 \mu \mathrm{g} / \mathrm{m}^{2}$ are added annually to the watershed. The augmented total annual mercury deposition rate of about $25-29 \mu \mathrm{g} / \mathrm{m}^{2}$ is high, but is comparable to what is estimated for the northeastern and Gulf Coast states in the U.S. Thus, the responses measured by the METAALICUS researchers should provide insights to the mercury research community, and have relevance to policy makers. After the final year of mercury additions, the METAALICUS study lake and its watershed will become the site of an another experiment in mercury loading reduction.

\section{Source-Apportionment for Atmospheric Mercury Deposition: Where Does The Mercury in Mercury Deposition Come From?}

By M. Cohen', R. Draxler², and R. Artz ${ }^{3}$

${ }^{1}$ NOAA Air Resources Laboratory, Silver Spring, MD (mark.cohen@noaa.gov)

${ }^{2}$ NOAA Air Resources Laboratory, Silver Spring, MD (roland.draxler@noaa.gov)

${ }^{3}$ NOAA Air Resources Laboratory, Silver Spring, MD (richard.artz@noaa.gov)

Atmospheric deposition of mercury is a very significant contamination pathway for many ecosystems. In order to make rational plans for amelioration, it is not enough to simply know how much mercury is being deposited into a given ecosystem. One must also have information regarding where the mercury is coming from. How much of the mercury is coming from local, regional, national, continental, or global sources? What is the relative importance of different source types? For the atmospheric pathway, one must utilize models to develop such source-receptor information. Ambient measurements play a critical role in providing a means to evaluate and refine models. Unfortunately, data for model evaluation are scarce. While there is an established network of wet deposition monitoring stations (MDN) there are few measurements of ambient mercury separated into its different forms: ionic $[\mathrm{Hg}(\mathrm{i})]$, particulate $[\operatorname{Hg}(\mathrm{p})]$, and elemental $[\mathrm{Hg}(0)]$. There are a number of uncertainties in current atmospheric mercury models but most are able to produce results that are reasonably consistent with observed measurements.

The fate and transport of atmospheric mercury is being modeled using a specially configured version of the NOAA HYSPLIT_4 model along with a post-processing methodology that allows detailed source-receptor information to be estimated. This modeling system has been shown to provide realistic results in comparison with other atmospheric mercury models and ambient measurements (Ryaboshapko and others, 2003) and has been used to analyze atmospheric deposition to the Great Lakes (Cohen and others, 2004).

The form of emitted mercury strongly influences its fate and transport. For example, illustrative simulations show that with $\mathrm{Hg}(\mathrm{i})$ emissions, approximately 30 percent of the emit- 
ted mercury is deposited within 120 kilometers $(\mathrm{km})$, while only 2 percent and 0.2 percent of $\mathrm{Hg}(\mathrm{p})$ and $\mathrm{Hg}(0)$ emissions, respectively, are deposited within the same distance of a 250-meter-high source. Illustrative simulations also show that the impact of any given source on any given receptor is very episodic. An example of the overall modeling system results are shown for the Chesapeake Bay based on estimated 1999 anthropogenic emissions in the U.S. and Canada. Approximately 60 percent of the modeled deposition to the Bay arises from sources within $100 \mathrm{~km}$ of its shores. Based on the model results, the top contributing individual sources appear to be primarily coal-fired power plants and waste incinerators.

\section{References Cited}

Cohen, M., Artz, R., Draxler, R., and others, 2004, Modeling the atmospheric transport and deposition of mercury to the Great Lakes: Environmental Research, v. 95, p. 247-265.

Ryaboshapko, A., and others, 2003, Intercomparison study of numerical models for long-range atmospheric transport of mercury, Stage II-Comparison of modeling results with observations obtained during short-term measuring campaigns: Moscow, Russia, MSC-East.

\section{Atmospheric Chemistry and the Relative Importance of Emission Sources}

By 0. Russell Bullock, Jr. ${ }^{1}$

${ }^{1}$ NOAA Air Resources Laboratory, on assignment to the U.S. Environmental Protection Agency, Research Triangle Park, NC (bullock.russell@epa.gov)

Various atmospheric chemical reactions are known to affect the oxidation state of mercury in air and in cloud water. Elemental mercury from the atmosphere is deposited relatively slowly and has a much longer atmospheric lifetime than the more reactive oxidized mercury compounds. Thus, atmospheric chemistry affects the transport potential of mercury emitted to air and the distance these emissions can travel before they are eventually deposited. The primary question being asked by environmental regulatory authorities is "where is the mercury coming from that is depositing to my watershed or water body of interest?" Answering this question with any confidence requires an understanding of the chemical reactions and resulting atmospheric behavior of mercury emitted from all potentially important emission sources. This understanding is still being developed, but a cursory description and analysis of the atmospheric lifetime of mercury is offered here to help give approximate answers to this serious question.

The forms of mercury currently measurable in the atmosphere are discussed, as are the reactions that are currently recognized to transform mercury from each of these forms to another. Simple graphical schematics of the transport characteristics of the gaseous forms of mercury under various conditions are provided. Finally, a hypothetical analysis of the relative importance of foreign and domestic (United States) sources of mercury is described. In this analysis, the range of the atmospheric lifetime of elemental mercury between 6 and 24 months is examined. The results show that, under the hypothetical conditions set forth, foreign sources of mercury could be responsible for 74 percent of the mercury depositing in the U.S. when the 6-month lifetime is assumed and 45 percent when the 24 -month lifetime is assumed. This lower contribution from foreign sources under the longer lifetime assumption is somewhat counterintuitive since longer lifetimes would support longer transport distances. However, both the 6- and 24-month lifetimes are more than sufficient to allow global homogenization of foreign emissions. Thus, the rate of deposition of those emissions as they travel across the U.S. is a more important factor in their contribution to total domestic deposition.

DISCLAIMER: The research presented here was performed under the Memorandum of Understanding between the U.S. Environmental Protection Agency (USEPA) and the U.S. Department of Commerce's National Oceanic and Atmospheric Administration (NOAA) and under agreement number DW13921548. Although it has been reviewed by USEPA and NOAA and approved for publication, it does not necessarily reflect their policies or views.

\section{Petroleum Drilling Fluids as a Source of Mercury to the Offshore Environment}

By J.H. Trefry

${ }^{1}$ Florida Institute of Technology, Melbourne, FL (jtrefry@fit.edu)

Mercury $(\mathrm{Hg})$ is a natural impurity in barite $\left(\mathrm{BaSO}_{4}\right)$, a weighting agent used in petroleum drilling fluids. Concentrations of mercury in natural barite from diverse sources range from $<50$ to $>10,000$ nanograms per gram (ng/g). However, the U.S. regulates allowable levels of $\mathrm{Hg}$ in barite used for drilling fluids at $<1,000 \mathrm{ng} / \mathrm{g}(1 \mathrm{ppm})$. Some studies have shown that mercury in industrial barite can be bound in sulfide phases such as sphalerite $(\mathrm{ZnS})$ that can be present as impurities in barite ore. Less than 0.1 percent of the mercury in industrial barite is released into solution at $\mathrm{pH} 2.2$ or in 10 percent acetic acid. Where barite and other drilling-fluid components are discharged into offshore waters, concentrations of mercury in bottom sediments vary from background levels of $\sim 40 \mathrm{ng} / \mathrm{g}$ to levels as high as $800 \mathrm{ng} / \mathrm{g}$. During 2002, a study was carried out in the Gulf of Mexico to determine whether drilling discharges lead to enhanced concentrations of methylmercury in sediments near drilling sites. Surface $(0-2$ centimeters $(\mathrm{cm}))$ and subsurface $(2-20 \mathrm{~cm})$ sediments were collected at $<100$ meters $(\mathrm{m})$ from the drilling site (nearfield) and $>3 \mathrm{~km}$ from the drilling site (far-field). Concentrations of total mercury were significantly higher at near-field stations (range $25-558 \mathrm{ng} / \mathrm{g}, \mathrm{n}=109$ ) than at far-field stations (range 11-92 ng/g, $\mathrm{n}=62$ ) for five of the six drilling sites due to inputs from drilling discharges. In near-field sediments where total mercury levels exceeded background levels, concentrations of Ba ranged from 2-28 percent (dry weight), relative to background $\mathrm{Ba}$ concentrations of about 0.05-0.15 percent. A strong linear relationship between 
concentrations of $\mathrm{Ba}$ and total $\mathrm{Hg}$ in sediments from near-field stations, coupled with the high levels of $\mathrm{Ba}$ as barite in these sediments, support the contention that barite was the primary source for anthropogenic mercury in these sediments. Concentrations of methylmercury ranged from $0.11-1.05 \mathrm{ng} / \mathrm{g}$ with a mean of $0.44 \pm 0.27 \mathrm{ng} / \mathrm{g}$ for all far-field sediments and ranged from $<0.03-2.7 \mathrm{ng} / \mathrm{g}$ with a mean of $0.45 \pm 0.41 \mathrm{ng} / \mathrm{g}$ for all near-field sediments. In contrast with results for total mercury, this study showed that concentrations of methylmercury in sediment from all six drilling sites did not vary significantly between near-field and far-field stations. However, considerable variability was observed in concentrations of methylmercury at several sites and was partly related to local variability in redox state in the upper $10 \mathrm{~cm}$ of sediment. Low to nondetectable levels of methylmercury were observed in near-field stations where the redox potential (Eh) was $<-100 \mathrm{mV}$ (anoxic and highly reducing) in the presence of abundant total $\mathrm{H} 2 \mathrm{~S}$ (>1 millimolar). Higher values of methylmercury were found in a few near-field stations where levels of total organic carbon were higher and where Eh values were about $0 \mathrm{mV}$ (anoxic, moderately reducing). These observations are consistent with studies showing that optimum conditions for methylmercury formation are in anoxic sediment with sulfide-poor interstitial water and sufficient levels of biodegradable organic matter and nutrients. With respect to the role of petroleum drilling fluids as a source of total mercury to Gulf of Mexico, the estimated input of mercury from drilling discharges is $300 \mathrm{~kg} / \mathrm{yr}$, $\sim 1$ percent of the total inputs from the Mississippi River $(21,000 \mathrm{~kg} / \mathrm{yr}$ with particles and $1,500 \mathrm{~kg} / \mathrm{yr}$ dissolved) and the atmosphere $(5,100 \mathrm{~kg} / \mathrm{yr})$.

\section{Session 6: Influence of Ecosystem Setting on Mercury and Mercury Management}

Moderator: Adria Elskus, University of Kentucky

\section{Session Summary}

This session was an extension of the case-study session (Session 2). These presentations added more detailed information about the factors influencing mercury methylation described in the case-study session and described some strategies for controlling mercury mobilization as well as for long-term mercury monitoring. Although recently deposited mercury may be most bioavailable, mercury deposited in the past, as described in one presentation, may be remobilized through soil disturbances such as erosion or burning. Salt and freshwater wetlands are ecosystems long associated with generation of methylmercury. Methylation in wetlands of the Everglades, the Gulf coast, and San Francisco Bay were compared in a presentation that concluded that more research would be needed to predict methylation rates in these environments. A detailed mercury investigation of paired watersheds in Acadia National Park pointed to long-term effects of land management on mercury cycling, including changes in plant species and related changes in dry-deposition rate resulting from burned watersheds.

\section{Abstracts}

Mercury Bioaccumulation in Stream EcosystemsDetailed Studies, Spatial Assessments, and Trend Monitoring

By M.E. Brigham ${ }^{1}$

${ }^{1}$ U.S. Geological Survey, Mounds View, MN (mbrigham@usgs.gov)

Management of ecosystems that contain mercury-sensitive waters (lakes or streams with relatively high levels of mercury in fish or other biota) may benefit from consideration of research on mercury cycling, bioaccumulation, and related environmental issues. Mercury stored in soils from past deposition represents a notable environmental pool of mercury. Retaining this mercury in upland portions of watersheds, rather than promoting its transport to aquatic ecosystems, is one strategy that may help ameliorate mercury bioaccumulation in some ecosystems. Activities that exacerbate erosion of surficial soils or weathering of soil-organic carbon may greatly increase loading of mercury to aquatic ecosystems. Other land-based influences, such as increases in impervious areas resulting from urbanization or low-intensity fires, also may exacerbate transport of mercury from uplands to aquatic ecosystems. Land-management practices that restore soil-organic carbon, such as certain soil conservation measures, may help retain atmospherically deposited mercury on the land surface.

In addition to the transport of mercury, mercury methylation-a critical step in the mercury bioaccumulation cyclecan be influenced by environmental processes that intersect with human activities. Creation of reservoirs or impoundments promotes methylation of mercury. Methylation of mercury also has been exacerbated in many ecosystems by repeated wetting and drying cycles, which may be influenced by hydrologic modifications; and inputs of sulfate from atmospheric, agricultural, or other sources.

To improve understanding of mercury bioaccumulation in stream ecosystems, the U.S. Geological Survey is conducting detailed studies at two streams in Oregon, three in Wisconsin, and three in Florida. In general, atmospheric deposition of mercury increases along this west-to-east gradient, and methylmercury production and bioaccumulation in fish is more prominent in low-relief, high-wetland stream basins. Study streams drain a range of settings-reference areas, with minimal human disturbances, to highly urbanized settings. These studies aim to describe concentrations and fluxes of mercury in key components of the stream ecosystem: water, streambed sediment, porewater, and biota. Detailed studies are supplemented by spatial assessments of variations in mercury bioaccumulation through one-time (synoptic) sampling of mercury and methylmercury in water, sediment, and fish tissues at several hundred streams across the nation, covering a diverse 
range of settings and sources. One finding from spatial assessments is that some coastal blackwater streams of the southeastern United States, despite having total mercury concentrations 1-2 orders of magnitude lower than mining-affected streams, have aqueous methylmercury and fish-mercury concentrations comparable to some mining-affected streams of the West. This surprising result illustrates the importance of mercury methylation as a driver of mercury bioaccumulation. Lastly, we seek to maintain a small network of sites for long-term monitoring of mercury in precipitation, water, and fish.

\section{Watershed Factors Influencing Bioaccumulation of Mercury \\ By Neil C. Kamman' \\ ${ }^{1}$ Vermont Department of Environmental Conservation, Waterbury, VT (neil.kamman@state.vt.us)}

Watershed factors explain some of the significant geographic heterogeneity in biotic mercury $(\mathrm{Hg})$ concentrations observed across the north-temperate landscape. Dissolved organic carbon (DOC), acidity, and sulfate are three master variables controlling $\mathrm{Hg}$ movement through watersheds, and bioaccumulation of $\mathrm{Hg}$ to biota. DOC of terrigenous origin is responsible for $\mathrm{Hg}$ transport to and through drainage networks, and the low $\mathrm{pH}$ values characteristic of high DOC watersheds increase $\mathrm{Hg}$ solubility and facilitate methylmercury uptake. Exemplar watersheds are typically forested and wetland-rich, and the foliar accumulation of atmospherically deposited $\mathrm{Hg}$ accounts for a significant proportion of the annual $\mathrm{Hg}$ deposition to such watersheds. The methylation of $\mathrm{Hg}$ by sulfurreducing bacteria requires sulfate, and is favored in reducing environments (e.g., sediments, wetlands) and in environments that experience rapid switching of the redox state. Thus, acidic forested watersheds typically display the highest concentrations of $\mathrm{Hg}$ in fish and other biota. Other watershed factors superimposed upon these basic drivers of $\mathrm{Hg}$ bioaccumulation serve to enhance or dampen the bioaccumulation signal in biota, and can be likened to "plus" and "minus" factors.

Lakes with high levels of nutrients and primary production can reduce the efficiency with which $\mathrm{Hg}$ bioaccumulates through food webs, due to algal bloom dilution and zooplankton density dilution. Where algal production and associated primary consumer populations are large, $\mathrm{Hg}$ concentrations are lesser in fish and other biota, as less $\mathrm{Hg}$ is available to these secondary or higher-level consumers per unit of primary production (less Hg per bite of algae). Due to this mechanism, watershed land uses that are known to cause increased nutrient loading (urban or agricultural lands) have receiving waters that may be lower in fish $\mathrm{Hg}$ levels. Therefore, where eutrophication is actively being managed to reduce trophic state, $\mathrm{Hg}$ in biota may increase with time. Water-level fluctuation in lentic reservoirs may also enhance bioaccumulation of $\mathrm{Hg}$, by promoting redox switching in the periodically de-watered and reinundated littoral zone, resulting in generation of bioavailable methylmercury that is released to the reservoir waters during refilling. Fire and logging both create situations where large quantities of DOC can be released to watershed drainage networks. Log jobs have been shown to result in short-term increases in methylmercury accumulation to zooplankton. By contrast, burned watersheds do not show a short-term increase in Hg in biota, as much of the foliar and surficial soil-bound $\mathrm{Hg}$ is volatilized off the watershed during the burn, despite increased DOC loading; however, fire still may play an important role in $\mathrm{Hg}$ bioaccumulation. As "new" $\mathrm{Hg}$ is deposited to a newly burned landscape, the transfer of that most readily methylated $\mathrm{Hg}$ to downstream waters can be expected to be rapid. These "plus" and "minus" factors associated with $\mathrm{Hg}$ could be considered by DOI land managers when planning management activities that disturb, inundate, or burn lands. Long-term monitoring of $\mathrm{Hg}$ in biota could also be considered in lands and waters that DOI resource managers oversee.

\section{Wetland Restoration and the Potential for Enhanced Mercury Methylation}

By Mark Marvin-DiPasquale ${ }^{1}$

\section{${ }^{1}$ U.S. Geological Survey, Menlo Park, CA}

Wetlands are known to be active zones of toxic methylmercury $(\mathrm{MeHg})$ production, although the specific biogeochemical processes that drive this are poorly understood. Consequently, there has been widespread discussion and concern that many ongoing and planned wetland restoration activities may lead to a net increase in $\mathrm{MeHg}$ production and bioaccumulation in local food webs. While this possibility cannot be ruled out, the extent to which it will occur, and over what temporal and spatial scales, is not currently known. Data are presented from recent USGS ecosystem-level mercury investigations conducted in San Francisco Bay (SFB), California; the Florida Everglades; and the Lake Pontchartrain Basin, Louisiana. To better understand the physical, geochemical, and microbial processes that control $\mathrm{MeHg}$ production rates within and among wetlands, these studies were conducted at multiple scales (sub-habitat, watershed, and inter-regional). At the smallest scale, strong spatial and seasonal differences in $\mathrm{MeHg}$ production rates are observed in a comparison of SFB sediments associated with wetland plants to those from immediately adjacent, non-vegetated mudflats. Results are explained in terms of changes in iron and sulfur oxidation-reduction chemistry associated with the active transport of oxygen into sediments by saltmarsh plants. At the watershed scale, SFB saltmarsh sediments had higher rates of $\mathrm{MeHg}$ production than deep-water, non-vegetated sites (open-bay, reservoir, or river sites), and than delta and freshwater wetland sites. The most pristine (least eutrophic) Everglades site exhibited the highest rates of $\mathrm{MeHg}$ production and the strongest response to changing temperature. The inhibitory effect of high porewater sulfide levels on MeHg production is demonstrated for the Everglades. Wetland sites in Lake Pontchartrain had higher average $\mathrm{MeHg}$ production rates than lake and river sites from the same system. Freshwater swamps dominated by cypress and tupelo vegetation had higher levels of reactive $\mathrm{Hg}$ (II) in sediment than a more sulfide-rich Spartina marsh in this system, which 
led to higher measured rates of $\mathrm{MeHg}$ production in the former wetland type. Comparing ecosystems, $\mathrm{MeHg}$ production rates from Lake Pontchartrain wetlands were of similar range and magnitude to those from the estuarine portion of the SFB, and both were higher than the Everglades and delta and freshwater wetlands of the SFB. It remains a difficult problem to predict $\mathrm{MeHg}$ production rates in various wetland types; the long-term goal of this research is to develop an understanding of the relative rates of sediment $\mathrm{MeHg}$ at various spatial scales, which may ultimately assist resource managers in designing wetland restoration strategies that minimize net $\mathrm{MeHg}$ production and bioaccumulation.

\section{Landscape Control on Mercury Biogeochemistry in Gauged Paired Watersheds at Acadia National Park}

[Title in agenda: Mercury Biogeochemistry in Two Gauged Watersheds, Acadia National Park]

By Steve Kahl', Sarah Nelson², Ken Johnson², Katherine Sheehan², Ivan Fernandez, Aria Amirbahman², Terry Haines ${ }^{3}$, and Robert Lent ${ }^{4}$

\footnotetext{
'Plymouth State University, Plymouth, NH

${ }^{2}$ University of Maine, Orono, ME

${ }^{3}$ U.S. Geological Survey, Orono, ME

${ }^{4}$ U.S. Geological Survey, Augusta, ME
}

Two upland watersheds at Acadia National Park (Acadia NP), U.S. (44 ${ }^{\circ} 20^{\prime} \mathrm{N}$ latitude; $68^{\circ} 15^{\prime} \mathrm{E}$ longitude) were instrumented in 1998 to provide a long-term foundation for ecological and watershed research at Acadia NP, representative of coastal ecosystems of the Gulf of Maine. The research was initiated as part of USEPA/NPS PRIMENet (Park Research and Intensive Monitoring of Ecosystems Network), a system of UV-monitoring stations and long-term watershed research sites located in U.S. national parks. A main goal was to address watershed research questions about mercury, based on natural differences in forests and soils induced by an intense wildfire in one watershed in 1947. The unburned 47-hectare (ha) Hadlock Brook watershed is 70 percent spruce-fir mature softwood forest. In contrast, the nearby burned 32-ha Cadillac Brook watershed is 20 percent regenerating mixed northern hardwoods and 60 percent shrub/rocky balds.

Mercury $(\mathrm{Hg})$ deposition is higher in the unburned Hadlock watershed $\left(10.2 \mu \mathrm{g} / \mathrm{m}^{2} / \mathrm{yr}\right)$ than Cadillac $\left(9.4 \mu \mathrm{g} / \mathrm{m}^{2} / \mathrm{yr}\right)$ because of the greater scavenging efficiency of the softwood vegetation in Hadlock. As is typical in other studies around the world, methylmercury $(\mathrm{MeHg})$ is less than 1 percent of the total deposition to the landscape, underscoring that there is little justification for the high cost of monitoring $\mathrm{MeHg}$ in deposition. A marine re-volatilization source of $\mathrm{Hg}$ in deposition does not appear to be a major factor, because $\mathrm{Cl}$ and $\mathrm{Hg}$ concentrations in deposition are out of phase. Mercury export is lower in Cadillac Brook $\left(0.4 \mu \mathrm{g} / \mathrm{m}^{2} / \mathrm{yr}\right)$ than in Hadlock Brook $\left(1.3 \mu \mathrm{g} / \mathrm{m}^{2} / \mathrm{yr}\right)$ because of elemental volatilization during the fire that reduced total $\mathrm{Hg}$ in soils, along with subsequently lower rates of atmospheric re-deposition in a watershed with more bare soil and bedrock, and regenerating vegetation. In laboratory experiments, $\mathrm{Hg}$ has been shown to be less mobile in soils from the burned watershed. The results also show that $\mathrm{Hg}$ flux per hectare is greater from wetlands, but $\mathrm{Hg}$ flux per unit carbon is greater from uplands. Methyl-mercury was consistently less than 10 percent of total $\mathrm{Hg}$ flux in streamwater, regardless of streamflow or total $\mathrm{Hg}$ concentration. $\mathrm{MeHg}$ flux was not correlated with total $\mathrm{Hg}$ soil pools, suggesting that the mobile, bioavailable $\mathrm{Hg}$ pool is much smaller than total soil pools. If true, then decreases in total $\mathrm{Hg}$ from the atmosphere should result in decreased bioavailability of $\mathrm{Hg}$.

These data show that 50 years following a wildfire there was lower atmospheric deposition due to changes in forest species composition, lower soil pools, and greater ecosystem retention for $\mathrm{Hg}$ in the burned watershed. We propose that one of the controlling factors to explain the wide variation in $\mathrm{Hg}$ bioaccumulation in seemingly similar and adjacent lakes may be the hire of fire or other disturbance in the local landscape.

\section{Session 7: Moderators' Summaries and Suggested Future Research Directions for the DOI Landscape Mercury Initiative}

Moderator: Sarah Gerould, U.S. Geological Survey

\section{Session Summary}

Summaries of each session were presented at the end of the workshop by the session moderators. Included with these science summaries were appeals by the session moderators for more research products in forms that are useful to, and understandable by, land managers. Map products, for example, of mercury deposition, mercury methylation susceptibility, or mercury concentrations in fish, were suggested as particularly useful. Moderators also expressed a need for greater synthesis of data as a goal for future research.

After the summaries by moderators, discussion with conference participants began regarding the elements needed in a long-term strategy for mercury research that would increase communication between the mercury research community and DOI resource managers who deal with mercury effects. Land managers asked for research products that would be specific to their land areas on such topics as recommended land-management procedures for mitigating effects of mercury, monitoring strategies for mercury, and the criteria for judging necessity of a risk analysis. Scientists were encouraged, in the discussion, to pursue continued research but also were requested to produce interim products, so informed management can go forward with information that is already known.

An interesting example of a site-specific question on land management was given to illustrate the lack of improvement from management of the Cape Sable seaside sparrow. At least two management techniques, wet and dry cycling, and burning, are being done to enhance habitat, but these techniques may be increasing mercury methylation in the process. Population models (that do not include mercury effects) for 
the bird indicate its population should be increasing, but it is not. Perhaps the land-management practices that enhance the habitat for the bird in most respects are causing harm by increasing mercury effects.

During the discussion of future science directions, questions arose on the steps that bureaus should go through to determine the level of mercury effect that is associated with the resource that they manage. Several DOI resource-management bureaus requested that the USGS produce a document that would guide them in the basic stages of determining whether or not they have significant cause for concern with mercury at a given resource-management area. This request followed a lengthy discussion that indicated that more than a basic monitoring program is needed for mercury. USGS researchers at the workshop agreed with the recommendation for a mercury guidance document and felt that it would be extremely useful for identifying problem areas and protecting natural resources.

Managers of offshore resources asked for more basic research on mercury sources, cycling, and sinks. In the marine environment, many of the questions still remain for which progress has been made in the freshwater environment. For example, in the Gulf of Mexico, it is not known where mercury in marine fish comes from. Is it of anthropogenic or natural origin? What is the relative importance of mercury from the Mississippi River compared to other sources? How do such low concentrations of methylmercury in ocean waters get concentrated to such high levels in marine fish? What are the principal locations of mercury methylation for the marine environment? How does mercury accumulation and elimination in marine fish compare to freshwater species? What are the relative amounts of methylmercury and total mercury in marine species?

Several contributions to the discussion indicated that bigger scale, as yet unresolved, mercury questions also affect managers of land resources. For example, many species have not been evaluated with respect to mercury accumulation and effects. Wading birds, insectivorous birds, and other animals were mentioned. A second large-scale problem is the relationship between mercury sources and mercury receptors. Managers need to know what the prospects for mercury remediation of sources might be so they can plan long-term programs and know where and whether to advocate for mercury source reductions. Mercury research has progressed on the previously puzzling question of adjacent lakes with presumably similar deposition that have substantially different concentrations of mercury in fish. Many environmental factors- $\mathrm{pH}, \mathrm{DOC}$, sulfur, proximity of wetlands, trophic state, and water clarity-mediate the microbial conversion of mercury to methylmercury (methylation), as well as microbial demethylation. Variability among sites associated with these factors slows the progress of matching proximity and size of mercury sources with effects at receptor sites, and makes forecasting the result of emission remediation uncertain.
The extent to which "old mercury" (previously deposited mercury) continues to be active in the pool that may become methylated is unknown. We are not able to match predicted deposition from models with measured deposition from the Mercury Deposition Network very well. We do not know if there is a threshold of deposition rate beyond which increased mercury has little effect on methylation rate; that is, we do not know whether deposition and effect is linear or threshold-related. We are unsure of the mercury deposition rate (or atmospheric mercury residence time) associated with the background global mercury pool. We are unsure if background mercury deposition is sufficient to supply the threshold amount needed for methylation, or, again, if there is a threshold amount.

These questions relating to mercury source and receptor will likely require more mercury monitoring to answer. The DOI would likely play an important part in future efforts for increased, long-term monitoring. Monitoring ecosystems for mercury change that is caused by decreased emissions at mercury sources following remediation would help establish the relationship between source and receptor. A poster and several comments addressed strategies for implementing a network to monitor these kinds of changes.

The science of mercury environmental research has compelling evidence on the detrimental effects of mercury deposition from the atmosphere to the landscape. More investigation would be needed to determine how best to mitigate the effect of mercury already deposited on the landscape and to regulate mercury emissions to the atmosphere so that deposition will decrease to acceptable levels.

\section{Session 8: Poster Session}

\section{Session Summary}

The contributed posters on mercury covered a variety of topics and complemented the invited oral presentations. The posters addressed the effects of mercury on biota other than fish and humans, and included effects on salamanders, peregrine falcons, the great egret, and the bald eagle. Point sources as well as atmospheric sources of mercury were considered. Variability in mercury in coal deposits in the United States was described. Beneficial effects of fish consumption for nutritional health of human fetuses were described, emphasizing the need to fix the problem of mercury accumulation in fish, not just avoid fish consumption. Finally a national monitoring design was described. 


\section{Abstracts}

\section{Aqueous Stability of Mercury on Fly Ash}

\author{
By Ann G. Kim, Ph.D.' \\ ${ }^{1}$ National Energy Technology Laboratory, Pittsburgh, PA (akim_netl@usa. \\ com)
}

Increased controls on mercury emissions will shift the environmental burden from the flue gas to solid coal utilization by-products (CUB). If mercury can be leached from the CUB, it will have an impact on utilization, particularly uses that may allow transport of mercury from CUB to surface or ground water. Column-leaching studies of nine high mercury fly ash samples (3 from high mercury coal and 6 from PAC injection tests), indicated that mercury is soluble at high and low $\mathrm{pH}$. However, the cumulative amount of mercury leached was less than 0.01 of the amount present in the fly ash sample.

\section{Mercury Burdens and Trophic Position of the Crayfish \\ By Brenda Moraska Lafrancois ${ }^{1}$, and Daren M. Carlisle² (brenda_moraska_lafrancois@nps.gov)} Orconectes virilis in Voyageurs National Park, Minnesota

\footnotetext{
${ }^{1}$ National Park Service, Marine on St. Croix, MN
}

${ }^{2}$ U.S. Geological Survey, Reston, VA (dcarlisle@usgs.gov)

High mercury $(\mathrm{Hg})$ concentrations in fish and aquatic wildlife are common in the northern lakes of Voyageurs National Park. Crayfish are a key food web component, but little is known about their trophic position or $\mathrm{Hg}$ burdens. We explored how crayfish $\mathrm{Hg}$ body burdens relate to crayfish size, trophic position, watershed factors, and lake chemistry. Crayfish (Orconectes virilis) were collected from seven interior lakes at Voyageurs National Park in 2002 and 2003 using baited minnow traps. Each organism $(n=111)$ was analyzed for total mercury ( $\mathrm{THg}$ ), and a subset was analyzed for methylmercury (MeHg), (n=30 crayfish). Crayfish trophic position was determined using carbon and nitrogen stable isotope analysis ( $n=29$ crayfish). Watershed, morphometry, and chemistry data were assembled from previous studies. We used ANOVA to evaluate among-lake differences in crayfish $\mathrm{Hg}$, and a series of simple linear regressions to identify factors affecting crayfish $\mathrm{Hg}$ variation among lakes.

Crayfish included in this analysis represented a single age class. Total mercury averaged $51 \mathrm{ng} / \mathrm{g}$ and was dominated by the methylated form (mean $=88$ percent). Crayfish $\mathrm{THg}$ concentrations spanned an order of magnitude and differed significantly among lakes $(\mathrm{p}<0.001)$. Crayfish $\mathrm{THg}$ was not significantly correlated with crayfish body weight $(\mathrm{r}=-0.047$, $\mathrm{p}=0.623$ ) among lakes. ${ }^{13} \mathrm{C}$ and ${ }^{15} \mathrm{~N}$ signatures of crayfish differed little among lakes, and neither was significantly correlated with crayfish THg burden or body weight $(\alpha=0.1)$. Few watershed, morphometric, or chemical attributes explained a significant amount of variation in crayfish $\mathrm{THg}$. However, TOC independently explained 78 percent $(p=0.009)$ of the variation in mean crayfish $\mathrm{THg}$. Variation in crayfish $\mathrm{THg}$ was better explained by TOC than by crayfish body mass, trophic position, watershed factors, or lake morphometry. TOC also explained significant variation in water column $\mathrm{THg}$ and yellow perch THg in these lakes (Brent Knights, unpublished data). THg accumulation in the biota of interior lakes at Voyageurs may be strongly affected by watershed and in-lake processes controlling TOC concentrations.

\section{Mercury in the Pacific Outer Continental Shelf \\ By Dave Panzer'}

${ }^{1}$ USGS Minerals Management Service, Camarillo, CA

Sources of mercury $(\mathrm{Hg})$ from offshore oil and gas platforms in the Pacific Outer Continental Shelf (OCS) Region, offshore California, are discussed and compared to mercury input to the marine environment from other sources. Mercury from offshore oil and gas activities arise primarily from the discharge of drilling muds and, more specifically, from elemental mercury contained in the barite (barium sulfate) used routinely in the drilling process. Mercury is also discharged in produced water, a routine treated waste resulting from the production of oil, natural gas, and water. Approximately 4 kilograms $(\mathrm{kg})$ of mercury was discharged during the drilling of 122 selected wells and $0.0000012 \mathrm{~kg}$ was discharged from produced water, cumulatively, since 1990. Other sources include sewage-treatment plants, $20 \mathrm{~kg} \mathrm{Hg} /$ year; dredge spoil disposal, $180 \mathrm{~kg} \mathrm{Hg} /$ year; and nonpoint sources, $55.7 \mathrm{~kg} \mathrm{Hg} /$ year. Questions regarding the fate and effect of mercury discharged by oil-well drilling are presented, particularly focusing on the potential for methylation and subsequent bioavailability.

\section{Designing a Mercury TMDL Study for the South River, Virginia}

\section{By Jack Eggleston ${ }^{1}$}

\section{${ }^{1}$ U.S. Geological Survey, Richmond, VA}

The South River of Virginia and its downstream receiving waters, the South Fork Shenandoah River and the Shenandoah River, are contaminated with mercury. Fish tissue concentrations of mercury are above 2 parts per million (ppm), exceeding the Virginia Dept of Health standard of $0.5 \mathrm{ppm}$ and causing streams to be placed on Virginia's 303(d) list of impaired waters. The primary source of mercury is thought to be an industrial site in Waynesboro that discharged mercury waste from the 1920s through 1960. Other mercury sources, such as atmospheric deposition and unmonitored stormwater discharge may also be involved. Ongoing studies of the stream system are determining the distribution of mercury in the soil, water, ground water, and biota.

The Virginia Department of Environmental Quality is partnering with the USGS to perform a total maximum daily load (TMDL) study of the affected streams. Major questions to be answered include: What are fluxes of mercury into and 
out of the affected streams? What are net mercury methylation rates? What are the relative contributions of bioavailable mercury? To answer these questions, major data gaps will need to be filled. The most important data gaps involve methylmercury concentrations in surface water and near-stream sediments. Mercury concentrations in ground water will also need to be measured. The goal of the study is to answer these questions with as much certainty as possible and to better understand why mercury concentrations in fish tissue remain high 40 years after the mercury waste disposal stopped.

\section{An Assessment of Risk of Methylmercury Exposure to Fish-Eating Birds Foraging at a Constructed Wetland in South Florida}

\section{By Darren G. Rumbold ${ }^{1}$}

${ }^{1}$ South Florida Water Management District, Ft. Myers, Florida

Stormwater Treatment Area - 2 (STA-2) was designed with three independent treatment marshes to remove phosphorus in agricultural runoff and reduce eutrophication in the northern Everglades. However, there was a concern that, in doing so, STA-2 might inadvertently worsen the existing mercury problem in the Everglades. Accordingly, operating permits required start-up monitoring of total mercury and methylmercury $(\mathrm{MeHg}$ ) and authorized flow-through operation only after concentrations in the interior marsh were not significantly greater than concentrations in the supply canal. This case study summarizes an assessment of the risk of $\mathrm{MeHg}$ exposure to fish-eating birds required as a permit modification to authorize flow-through operation of Cell 1 without it first satisfying this start-up criteria. The assessment estimates the risks posed by $\mathrm{MeHg}$ to the great egret (Ardea alba) and the bald eagle (Haliaeetus leucocephalus). Exposure models were based on literature-derived life-history parameters combined with site-specific $\mathrm{MeHg}$ concentrations in water, sediment, and fish. To assess risk, daily $\mathrm{MeHg}$ intake by females and cumulative $\mathrm{MeHg}$ consumed by nestlings were compared to literature-derived effects thresholds. The results indicated a low likelihood that $\mathrm{MeHg}$ exposures to birds foraging throughout STA-2 would exceed effects thresholds at the time of this assessment. Birds foraging exclusively from Cell 1 or the small discharge canal were predicted to experience greater exposures and could be at potential risk. However, this worst case risk was comparable or lower than risk levels encountered in nearby water conservation areas or in Everglades National Park. Due to limitations in published effects thresholds, confidence in the risk characterization was lower for older eaglets remaining near their natal nest in the STA. Finally, there was no evidence that discharges from STA-2 have increased the risk of $\mathrm{MeHg}$ exposures immediately downstream of the STA above those of background risk levels.

\section{Mercury Bioaccumulation in Lotic Salamanders: A} Review and Assessment

\author{
By Michael Bank', Aria Amirbahman², and Robin E. Jung ${ }^{3}$ \\ ${ }^{1}$ Harvard University, Harvard Forest, Petersham, MA \\ ${ }^{2}$ Department of Civil and Environmental Engineering, University of Maine, \\ Orono, ME \\ ${ }^{3}$ USGS, Patuxent Wildlife Research Center, Laurel, MD
}

Mercury $(\mathrm{Hg}$ ) bioaccumulation in salamanders has received little attention despite widespread $\mathrm{Hg}$ contamination of aquatic ecosystems and worldwide amphibian declines. Here we report a review of $\mathrm{Hg}$ contamination in larval northern two-lined salamanders (Eurycea bislineata bislineata) collected from streams in Acadia National Park (ANP), Maine, and Bear Brook Watershed, Maine (BBWM) - a paired, gauged watershed treated with bimonthly applications $(25 \mathrm{~kg} / \mathrm{ha} / \mathrm{yr})$ of ammonium sulfate $\left.\left[\left(\mathrm{NH}_{4}\right)_{2} \mathrm{SO}_{4}\right]\right)$ since 1989 and Shenandoah National Park (SNP), Virginia. Our results suggest that watershed-scale attributes including fire history, whole-catchment $\left(\mathrm{NH}_{4}\right)_{2} \mathrm{SO}_{4}$ additions, wetland extent, and forest cover type influence $\mathrm{Hg}$ bioaccumulation in two-lined salamanders inhabiting lotic environments. We also discuss future research directions to evaluate $\mathrm{Hg}$ bioaccumulation in stream ecosystems at existing long-term ecological research sites in the northeastern United States. Long-term, broad-scale studies that address variation in $\mathrm{Hg}$ cycling across a wide gradient of physical, climatic, and biotic conditions will allow researchers to develop a more synthesized perspective on patterns and processes related to fate, transport, and bioavailability of $\mathrm{Hg}$ in aquatic ecosystems.

\section{Mercury Emissions and Lake Deposition: A Qualitative Model and Its Application to Lake Whatcom, Washington}

\section{By Anthony J. Paulson and Dale Norton}

A simple atmospheric deposition model was developed that allowed comparisons of the deposition of mercury $(\mathrm{Hg})$ to the surfaces of lakes in Whatcom County, Washington. The model required wind data, $\mathrm{Hg}$ emission rates from each source, an estimate of the speciation of $\mathrm{Hg}$ in the emissions (particulate, reactive, or vaporous $\mathrm{Hg}$ ) of each type of $\mathrm{Hg}$ source, and the atmospheric residence time of each $\mathrm{Hg}$ species. Of all the lakes examined, basin 1 of Lake Whatcom would have been most affected by the $\mathrm{Hg}$ emissions from the chlor-alkali plant that operated in the City of Bellingham until 2000. The down-lake decrease in estimated atmospheric deposition to Lake Whatcom was not reflected in the enrichment of $\mathrm{Hg}$ in the sediments above pre-industrial concentrations. The enrichment ratios of 2 to 3 in the sediment from throughout Lake Whatcom were on the lower end of values of enrichment ratios found across the U.S. The length-adjusted concentrations of $\mathrm{Hg}$ in largemouth and smallmouth bass were not related to estimated deposition rates of $\mathrm{Hg}$ to the lakes from local atmospheric sources. Estimates of $\mathrm{Hg}$ deposition derived from the model indicated that the most significant deposition 
of $\mathrm{Hg}$ attributed to local sources would have occurred to the lakes north of the City of Bellingham. These lakes are in the primary wind pattern of two municipal waste incinerators that closed in 1997.

\section{Mercury Deposition and Bioaccumulation Along an Urban Gradient in New England}

\author{
By A. Chalmers', D. Krabbenhoft'2, M. Nilles ${ }^{3}$, E. Prestbo ${ }^{4}$, and \\ M. Olson ${ }^{5}$ \\ 'U.S. Geological Survey, Montpelier, VT (chalmers@usgs.gov) \\ ${ }^{2}$ U.S. Geological Survey, Middleton, WI (dpkrabbe@usgs.gov \\ ${ }^{3}$ U.S. Geological Survey, Lakewood, CO (manilles@usgs.gov) \\ ${ }^{4}$ Frontier Geosciences, Seattle, WA (ericp@ frontiergeosciences.com) \\ ${ }^{5}$ U.S. Geological Survey, Middleton, WI (mlolson@usgs.gov)
}

We examined how concentrations of mercury in stream water, sediment, fish tissue, and atmospheric deposition varied according to a gradient of urbanization around the Boston metropolitan area. Concentrations of total mercury (THg) and methylmercury ( $\mathrm{MeHg}$ ) in water, bed sediment, and fish tissue were evaluated to determine patterns of $\mathrm{MeHg}$ accumulation and partitioning, relative to site and watershed conditions, at 55 stream sites from Rhode Island to Maine during 1998-2000; 27 of the 55 stream sites had fish-tissue data collected. Urban areas tended to have high $\mathrm{THg}$ concentrations in water and streambed sediments, but low concentrations of THg in fish. Relatively undisturbed ecosystems had greater methylation potential, as estimated by the ratio of $\mathrm{MeHg}$ to $\mathrm{THg}$, compared to highly urbanized sites. Concentrations of mercury (> 95 percent $\mathrm{MeHg}$ ) in fish were highest in relatively undisturbed ecosystems near urban areas.

Sediment cores were collected in 2000 from three lakes considered to be reference sites for atmospheric deposition within the region studied. Levels of mercury in these cores characterize conditions during the past 30 years and indicate that an order of magnitude difference in mass accumulation rates of THg among the sites may be due to differences in atmospheric deposition rates.

During 2002-04, biweekly wet-deposition samples were collected from four atmospheric deposition samplers located along a gradient of urbanization around the Boston metropoli$\tan$ area. Median concentrations of $\mathrm{HgT}$ in wet deposition for 2002-03 were greater, by about 25 percent, at the urbanized locations near Boston than at the rural location in central New Hampshire. These results suggest that localized urban emission sources may have significant effects on concentrations of $\mathrm{Hg}$ in rainfall in New England, which in turn may result in variable deposition patterns on a sub-regional scale.

We hypothesize that the observed patterns in $\mathrm{Hg}$ concentrations in water, sediment, and fish tissue are controlled by a combination of ecosystem factors that influence methylation and atmospheric emissions.

\section{Mercury Exposure to Peregrine Falcons Nesting on Power Plant Stacks}

By Richard Carlton', Robert Anderson², and Amy Ries²

${ }^{1}$ Electric Power Research Institute, Palo Alto, CA

${ }^{2}$ Raptor Resource Project, Canton, MN

Introduction - In 1989, peregrine falcons (Falco peregrinus), which at that time were listed as an endangered species in the United States, began utilizing artificial nest boxes placed high on stacks at coal-fired power plants in the upper Midwest. Mae, the first peregrine to produce young on a power plant stack, fledged two chicks in 1990. Since then the power plant peregrine nesting program has grown rapidly so that peregrines fledged from power plant sites now comprise over 30 percent of the Midwest population. Compared to nests on buildings, cliffs, and bridges, power plant nests have the highest rates of nest productivity and chick-to-fledgling survival. Peregrine falcons currently nest at power plants in Minnesota, Iowa, Wisconsin, Kentucky, Kansas, Michigan, Indiana, and Ohio.

Coal-fired power plant boilers are known point sources of atmospheric mercury emissions. Therefore, even though there was no a priori indication of metal toxicity based on behavioral data, it was decided that peregrines nesting at coalfired plants should be investigated to determine their risk for developing heavy metal toxicity over time. This study tracked concentrations of mercury, selenium, chromium, nickel, and arsenic in power plant-nesting peregrines over a three-year period, yielding a profile of each site's contaminant levels, and providing a baseline against which the contaminant levels of future peregrines can be measured.

Results - Peregrine falcons nesting at coal-fired plants had higher blood methylmercury concentrations than did peregrines nesting at nuclear power plants or in urban locations. However, peregrines at coal-fired plants did not accumulate heavy metals at levels hazardous to their physical or reproductive health. Adult peregrines showed a stronger correlation between plant output of $\mathrm{Hg}(\mathrm{II})$ and blood methylmercury concentrations than did chicks, suggesting that adults would make better bio-sentinels. Peregrine adults and chicks at coal-fired plants also accumulated selenium and chromium, but not at harmful levels. Urban nesting falcons had the highest levels of arsenic, while nickel exposure was apparently insignificant for all groups. Based on our results, peregrine falcons at coal-fired power plant sites do not appear to be at risk for significantly increased exposure to heavy metals when compared with falcons nesting at nuclear plants or in urban areas. Furthermore, on average, peregrines migrating through the Midwest from other latitudes had higher metals levels than did resident peregrines. 


\section{Modeling Uncertainty by Using Bayesian Networks for Mercury-Mitigation Decisions}

\section{By William Labiosa' ${ }^{1,2,3}$, Ross Shachter ${ }^{3}$, James Leckie², James Rytuba', and Alexander Wood'}

${ }^{1}$ U.S. Geological Survey, Menlo Park, CA

${ }^{2}$ Department of Civil and Environmental Engineering, Stanford University, Stanford, CA

${ }^{3}$ Department of Management Science and Engineering, Stanford University, Stanford, CA (labiosa@stanford.edu)

Several subwatersheds of the San Francisco Bay are listed as impaired under the Clean Water Act because of high mercury fish-tissue concentrations (Hg-fish) and elevated aqueous mercury $(\mathrm{Hg})$ concentrations. Mercury Total Maximum Daily Load (TMDL) regulations are currently being formulated for these watersheds and are in various states of completion. Decisions on control strategies are being made despite large uncertainties about current $\mathrm{Hg}$ loadings, relations between total $\mathrm{Hg}$ ( $\mathrm{THg}$ ) loading and methylmercury $(\mathrm{MeHg}$ ) formation, and relations between control efforts and $\mathrm{Hg}$-fish.

This work proposes a novel decision analytical alternative to the current use of safety factors and deterministic models for $\mathrm{Hg}$ TMDL decision support, one that is fully compatible with an adaptive management approach. The approach uses a probabilistic (Bayesian) network (BN) model of the relations between potential $\mathrm{Hg}$-control efforts, $\mathrm{THg}$ loadings, aqueous $\mathrm{MeHg}$ concentrations, and $\mathrm{Hg}$-fish in the Cache Creek watershed, a major source of mercury to the San Francisco Bay delta. The stochastic empirical models used to generate the needed probability distributions are based on the same empirical models currently being used by the Cache Creek Hg TMDL workgroup. The significant difference is that modelinput uncertainty and model error are explicitly included and propagated throughout the model by using BN algorithms.

Model results include (1) probabilistic estimates of flowconditional THg loads; (2) probabilistic estimates of the downstream effects of various control strategies on $\mathrm{THg}$ loadings; (3) probabilistic inferences about unmonitored $\mathrm{THg}$ sources given observations from monitored sources; and (4) probabilistic estimates of $\mathrm{THg}$ load and flow-conditional aqueous $\mathrm{MeHg}$ concentrations and $\mathrm{Hg}$-fish at the watershed level.

This work demonstrates an approach to handling uncertainty within a complex and highly uncertain TMDL decision process. The various sources of uncertainty are integrated and propagated as decision risk, allowing decision-makers to simultaneously consider uncertainties in mitigation/implementation costs and to meet various environmental/ecologic targets.

\section{Mercury and Methylmercury Dynamics in Stream Water in Vermont, USA}

\author{
By J. Shanley', P. Schuster' ${ }^{2}$ A. Chalmers ${ }^{3}$, and M. Marvin-DiPasquale ${ }^{4}$ \\ ${ }^{1}$ U.S. Geological Survey, Montpelier, VT (jshanley@usgs.gov) \\ ${ }^{2}$ U.S. Geological Survey, Boulder, CO (pschuste@usgs.gov) \\ ${ }^{3}$ U.S. Geological Survey, Montpelier, VT (chalmers@usgs.gov) \\ ${ }^{4}$ U.S. Geological Survey, Menlo Park, CA (mmarvin@usgs.gov)
}

Total mercury ( $\mathrm{Hg}$ ) and methylmercury $(\mathrm{MeHg})$ concentrations in stream water have been monitored in diverse landscape types (forested, agricultural, and urban) and basin sizes (2 hectares to 2,704 square kilometers) in Vermont, USA, to assess the conditions and mechanisms responsible for $\mathrm{Hg}$ movement from upland to lowland environments. Total $\mathrm{Hg}$ varied from 0.2 to 129 nanograms per liter (ng/L) and methylmercury ranged from $<0.04 \mathrm{ng} / \mathrm{L}$ to $2.56 \mathrm{ng} / \mathrm{L}$. Methylation, evaluated as the ratio of $\mathrm{MeHg}$ to $\mathrm{Hg}$, averaged near 2 percent despite the abundance of wetlands and mucky soils in the Vermont landscape. The highest concentrations of both $\mathrm{Hg}$ and $\mathrm{MeHg}$ occurred during high flows in association with elevated particulate organic carbon (POC) concentrations, and most of the annual export of $\mathrm{Hg}$ and $\mathrm{MeHg}$ occurred primarily in the particulate phase $(>0.45$ micrometer $(\mu \mathrm{m}))$ during brief high-flow episodes in all landscape types. At nearly all sites, mercury and methylmercury concentrations were positively correlated to each other and to stream discharge, suggesting a common source. This behavior contrasts to observations in Europe of dilution of methylmercury during high flows.

\section{Effects of Mercury Exposure on the Health and Fitness of Captive-Reared Common Loon (Gavia immer) Chicks \\ By Kevin P. Kenow ${ }^{1}$, Randy K. Hines², Michael W. Meyer ${ }^{3}$, Francois Fournier ${ }^{4}$, William H. Karasov ${ }^{5}$, David J. Hoffman ${ }^{6}$, Keith A. Grasman, Marilyn G. Spalding ${ }^{8}$, and Annette Gendron-Fitzpatrick ${ }^{9}$

\footnotetext{
${ }^{1}$ U.S. Geological Survey, La Crosse, WI (kkenow@usgs.gov)

${ }^{2}$ U.S. Geological Survey, La Crosse, WI (rhines@usgs.gov)

${ }^{3}$ Wisconsin Department of Natural Resources, Rhinelander, WI

${ }^{4}$ University of Wisconsin, Madison, WI (francois.fournier@bio.ulaval.ca)

${ }^{5}$ University of Wisconsin, Madison, WI (wkarasov@wisc.edu)

${ }^{6}$ U.S. Geological Survey, Beltsville, MD (dhoffman@usgs.gov)

${ }^{7}$ Wright State University, Dayton, OH (keith.grasman@wright.edu)

${ }^{8}$ University of Florida, Gainesville, FL (SpaldingM@mail.vetmed.ufl.edu)

${ }^{9}$ University of Wisconsin, Madison, WI (gendron@ rarc.wisc.edu)
} (Michael.Meyer@dnr.state.wi.us)}

Quantification of the impact of contaminant exposure on wild populations is complicated by the confounding effects of environmental stressors. We conducted a dose-response laboratory study, where the confounding stressors were controlled, to quantify the level of mercury exposure associated with negative effects on survival and fitness of captive-reared common loon chicks. A dose regimen was implemented that provided exposure levels that bracketed the relevant environmental exposure levels of methylmercury $(\mathrm{MeHg}$ ) found in 
loon chicks across North America. Response variables that we assessed included measures of growth, behavior, foraging efficiency, biochemical and histologic changes, and immune function. We observed no overt signs of mercury toxicosis and found no significant difference in general behavior with exposure level. Results of a phyto-hemagglutinin skin response test, to evaluate lymphocyte-mediated immunity, suggest that loon chick immune systems are compromised at an ecologically relevant dietary exposure level $(0.5 \mu \mathrm{g} \mathrm{MeHgCl} / \mathrm{g}$ wet food intake). Physiologic and histologic analyses have not yet been finalized. We detected differences in several variables with respect to source of eggs (from nests on low $\mathrm{pH} /$ higher $\mathrm{MeHg}$ vs. neutral $\mathrm{pH} /$ lower $\mathrm{MeHg}$ lakes). Relative to chicks from neutral-pH lakes, chicks from low-pH lakes exhibited 1) higher blood $\mathrm{Hg}$ levels at hatch, 2) 3.8 percent lower hatch mass, 3) 7 percent lower asymptotic mass, 4) more time on brooding platforms, and 5) lower level of response to taped parental calls. Rapid MeHg excretion during feather growth likely provides loon chicks some level of protection from $\mathrm{MeHg}$ toxicity. Lake-source effects suggest that in ovo exposure to $\mathrm{MeHg}$ or other factors related to lake $\mathrm{pH}$ may have consequences on chick development and fitness.

\section{Mercury Variation in Coal}

By Allan Kolker', L.J. Bragg², S.J. Tewalt², C.A. Palmer², J.A. Luppens², R.B. Finkelman², and L.F. Ruppert ${ }^{2}$

${ }^{1}$ U.S. Geological Survey, Eastern Energy Resources Team, Reston, VA (akolker@usgs.gov)

${ }^{2}$ U.S. Geological Survey, Eastern Energy Resources Team, Reston, VA

Coal in the U.S. (and world) shows variation in mercury content by basin, by rank, and within individual coal beds. The average mercury content of U.S. in-situ coals is $0.17 \mathrm{ppm}$ (Bragg and others, 1998, USGS Open-File Report 97-134), slightly higher than that for coals delivered to power stations (0.10 ppm; Quick and others, 2003, Environmental Geol., v. 43; both averages on a dry basis). This difference reflects: 1) the fact that many eastern coals undergo coal preparation (to reduce sulfur) before use, and 2), the increased use of low sulfur western coals, for which coal preparation is generally not needed.

Pyrite is the primary host of mercury in bituminous coals, as indicated by results of selective leaching studies and reconnaissance laser ablation ICP-MS analysis. In leaching studies, a pyrite association for mercury is indicated by the proportion of mercury leached with nitric acid, typically about 50 percent or more (Palmer and others, 1998, Proc. 15 ${ }^{\text {th }}$ Ann. Int. Pittsburgh Coal Conf.). Laser ablation ICP-MS analysis of individual pyrite grains in samples of three bituminous coals indicate mercury enrichment factors of 10's to 100's, relative to their whole coal values (Kolker and others, 2002, USGS Open-File Report 02-224). Other forms of mercury that can be present in coal include an organic association, and, in some unusually mercury-rich coals, $\mathrm{HgSe}$ (tiemannite), $\mathrm{HgS}$ (cinnabar), and even native mercury.
Comparison of coals on an energy-equivalent basis, considering both concentration and calorific value, is useful in assessing relative mercury loadings to coal-fired power stations. In this context, the overall mercury contribution of low-rank coals, such as lignite, can be disproportionately higher than that suggested by mercury concentration alone. Mercury commonly shows variations within coal basins and in individual coal beds, a consequence of the fact that diagenetic (or later) fluid interaction controlling mercury distribution takes place on both of these scales. In the Appalachian Basin, on average, coals in the central part of the Basin have lower mercury contents $(0.15 \mathrm{ppm})$, than those in the northern $(0.24 \mathrm{ppm})$ and southern $(0.21 \mathrm{ppm})$ parts of the Basin. Within an individual coal bed, such as the Pittsburgh coal, samples with mercury contents exceeding the mean value $(0.14 \pm$ 0.092 ppm; $n=148$ ) by 30 percent or more tend to be localized on a sub-county scale (USGS, 2001, Prof. Paper 1625-C). Detailed delineation of mercury distribution on a bed scale is needed for selective mining to exclude the most mercury-rich zones. Coal preparation is also effective in reducing mercury loading to power stations. Cleaning alone may be sufficient to achieve moderate levels of mercury reduction mandated for existing non-utility boilers, in pending USEPA regulations. Cleaning will not achieve high-percentage reductions specified for new non-utility boilers, and is likely to be required for control of mercury emissions from coal-fired utility power stations.

\section{FDA's Initiative to Address the Public Health Policy on Mercury}

By R. Dufault ${ }^{1}$

${ }^{1}$ U.S. Food and Drug Administration, Rockville, MD (renee.dufault@fda.gov)

The U.S. Food and Drug Administration (FDA) hopes to educate the science community on the public health issues related to mercury contamination in fish. Forty-nine states currently have fish advisories for mercury. The USEPA and FDA have issued a joint advisory warning pregnant women not to eat fish contaminated with mercury. Mercury's harmful effects to the developing fetus are well documented in the medical literature.

Unfortunately, pregnant women need fish as part of their dietary intake to prevent birth defects. Fish contain a substance called docosahexaenic acid (DHA). DHA is a key ingredient needed by pregnant women for healthy fetal development. There is compelling scientific evidence that Attention Deficit-Hyperactivity Disorder (ADHD) is a birth defect caused by deficiencies of maternal DHA during pregnancy (Ottoboni et al.).

The primary source of DHA is fish. The secondary source of DHA is poultry because we feed fishmeal to poultry. Because DHA is an essential nutrient to assure healthy fetal development, we must have sources of DHA that are not contaminated with mercury. 
Current policy is focused on reducing emissions from power plants, waste incinerators, and other point sources. Atmospheric mercury deposition is declining in many areas of the U.S., yet mercury concentrations in fish are rising in most areas. Could it be that wastewater discharges of mercury are the primary source of fish contamination? Mercury is in hundreds of products as a result of mercury use in the production of chlor-alkali products and dental amalgam. Mercury in wastewater is a tremendous problem for most municipalities. It comes from unregulated wastewater discharges from the dental sector and mercury-contaminated products that are discharged to the sanitary sewer systems.

Mercury-free fish are necessary to sustain human life and the problem of mercury in products will need to be addressed, perhaps through changes in public-health policy.

\section{Establishing a Network to Detect Trends in Mercury in Aquatic Ecosystems}

\section{By M.E. Brigham ${ }^{1}$}

\section{'U.S. Geological Survey, Mounds View, MN (mbrigham@usgs.gov)}

Several proposed regulatory actions to reduce mercury emissions are under consideration in the United States (see for example, http://www.epa.gov/mercury/). Reductions in atmospheric deposition of mercury to aquatic ecosystems are anticipated. There is considerable uncertainty, however, in predicting temporal and spatial responses to mercury-emission reductions among varied ecosystems across North America. Decreases in mercury bioaccumulation are expected, particularly in ecosystems where atmospheric deposition is the greatest source of mercury. There likely will be a considerable lag time in some ecosystems between reduced mercury inputs and reduced mercury in gamefish. Absent a comprehensive new initiative to monitor trends in aquatic ecosystems, better coordination of existing state and federal programs would produce a scientifically sound and policy-relevant network to evaluate ecosystem response to emission reductions. A coordinated network of long-term monitoring sites could generate useful data sets to assess mercury trends in key ecosystem components (precipitation, stream or lake water, and fish tissue). Co-locating stream and lake sites with existing National Atmospheric Deposition Program / Mercury Deposition Network sites is a critical collaboration that could yield nationally consistent mercury deposition data. Thoughtful sampling strategies for water and fish, tailored to specific site types (stream or lake) and site characteristics, would enhance effective integration of ongoing monitoring programs to monitor mercury trends in aquatic ecosystems.

\section{The Usefulness of Chorioallantoic Membranes in Measuring Harmful Levels of Mercury in Eggs}

By Gary H. Heinz' and David J. Hoffman²

${ }^{1}$ U.S. Geological Survey, Patuxent Wildlife Research Center, Beltsville, MD (gary_heinz@usgs.gov)

${ }^{2}$ U.S. Geological Survey, Patuxent Wildlife Research Center, Beltsville, MD (david_hoffman@usgs.gov)

Methylmercury has been suspected as a cause of impaired reproduction in some wild birds, but the confounding effects of other environmental stressors have made it difficult to determine the toxic threshold in eggs at which embryo mortality begins to occur. In field studies it would be very useful to know how much mercury was in eggs that hatched versus those that did not hatch, but obviously it is impossible to collect an egg for mercury analysis and still leave it in the nest to see if it hatches. The measurement of mercury levels in chorioallantoic membranes offers a way to estimate how much mercury was in a chick that hatched from an egg, and also in the whole fresh egg itself. As an embryo is developing, wastes are collected in a sac called the chorioallantoic membranes. When a chick hatches, this sac is left behind with the eggshell. Our goal was to determine whether there was any promise in using mercury concentrations in chorioallantoic membranes to predict mercury concentrations in hatchlings.

In a lab study we fed mallards (Anas platyrhynchos) a control diet or diets containing 5, 10, or 20 ppm mercury as methylmercury chloride. Eggs were allowed to hatch, and mercury concentrations in the hatchlings were compared to those in the chorioallantoic membranes left behind in the eggshells. Mercury was below a detection limit of $0.09 \mathrm{ppm}$ on a dry-weight basis in whole eggs, hatchlings, and chorioallantoic membranes of controls. When the data from eggs laid by mercury-treated females were expressed as common logarithms, a linear equation was created by which the concentration of mercury in a duckling could be predicted from the concentration of mercury in the chorioallantoic membranes from the same egg. Therefore, it seems that one could visit nests in the wild and use measurements of mercury in chorioallantoic membranes of hatched eggs to estimate mercury concentrations in those eggs when they were laid. The mercury levels in successful eggs could then be compared to levels in eggs that died, thus shedding more light on what constitute toxic thresholds of mercury in the eggs of various species of wild birds. 


\section{Egg Injections as a Means of Assessing the Embryotoxicity of Methylmercury}

By Gary H. Heinz', David J. Hoffman², and Shannon L. Kondrad ${ }^{3}$

${ }^{1}$ U.S. Geological Survey, Patuxent Wildlife Research Center, Beltsville, MD (gary_heinz@usgs.gov)

${ }^{2}$ U.S. Geological Survey, Patuxent Wildlife Research Center, Beltsville, MD (david_hoffman@usgs.gov)

${ }^{3}$ U.S. Geological Survey, Patuxent Wildlife Research Center, Beltsville, MD (skondrad@anri.barc.usda.gov)

Aquatic birds, particularly fish-eating species, are especially vulnerable to methylmercury poisoning. Findings from the field have suggested that some species, such as loons (Gavia immer), may be suffering from reproductive impairment from methylmercury in the diet of the adults. Unfortunately, no controlled laboratory breeding studies have been conducted with any of these fish-eating species to assess their sensitivity to methylmercury. Given the great cost and time required to breed wild birds in captivity in sufficient numbers to conduct controlled breeding studies, it is unlikely that many controlled studies will be done with fish-eating species. As an alternative, we developed a procedure by which the eggs of wild birds could be collected in the field, shipped to our lab, and injected with graded doses of methylmercury. Using the eggs of domesticated strains of species such as mallards (Anas platyrhynchos), ring-necked pheasants (Phasianus colchicus), and chickens (Gallus gallus), we developed methods for injecting eggs with methylmercury and incubating them in an artificial incubator.

We injected a geometric progression of methylmercury doses into the air cell of the eggs. The methylmercury is dissolved in corn oil and injected at the rate of 1 microliter of corn oil per gram of egg contents. The eggs of all species are injected when the embryos reach the developmental equivalent of a 3-day-old chicken embryo. Thus far, the eggs of 20 species of birds have been tested, and it is apparent that there are species differences in sensitivity to injected mercury. The results from laboratory breeding studies with mallards have often been used to establish a presumed harmful threshold of mercury in avian eggs; however, the embryos of some species of wild birds seem to be more sensitive to methylmercury than are the embryos of mallards. Consequently, a threshold of mercury in the eggs of mallards at which reproductive problems begin to occur may not be adequate to protect all species of wild birds.

\section{Will Regulations That Are Adequate to Protect Wildlife from Mercury Poisoning Also Provide Protection for Human Health?}

By Gary H. Heinz ${ }^{1}$ and David J. Hoffman²

${ }^{1}$ U.S. Geological Survey, Patuxent Wildlife Research Center, Beltsville, MD (gary_heinz@usgs.gov)

${ }^{2}$ U.S. Geological Survey, Patuxent Wildlife Research Center, Beltsville, MD (david_hoffman@usgs.gov)

The existence of methylmercury in the environment poses a risk to humans as well as wildlife. Wildlife are protected by guidelines that differ from those used to protect human health. For human health, the goal is to provide protection for even the most sensitive individuals, whereas for wildlife the focus is divided between individual health and sustaining viable populations. Another contrast between the protection of humans versus wildlife is that humans cannot be used in experimental toxicity studies, but for wildlife it is often possible to conduct studies with either the species of concern or a closely related species. Another important difference is that, unlike humans, wildlife are generally unable to avoid mercury contamination or limit their consumption of mercury-contaminated food; for this reason, wildlife may be more vulnerable to mercury poisoning than are humans.

The question is whether guidelines established to protect wildlife from mercury poisoning could also serve to protect human health (and vice versa). To answer this question, the guidelines established for humans need to be compared to those for wildlife. Avian embryos are believed to be among the most sensitive life stages of any type of wildlife to mercury poisoning. In one study, when mallards were fed a diet containing about $0.1 \mathrm{ppm}$ mercury on a wet-weight basis, reproduction was harmed. This value of about $0.1 \mathrm{ppm}$ mercury in the diet is the lowest that has been shown to be associated with harm to avian reproduction. By contrast, most human health guidelines recommend avoiding a steady diet of foods that contain between 0.4 to $1.0 \mathrm{ppm}$ mercury on a wet-weight basis. Because the wildlife dietary threshold of $0.1 \mathrm{ppm}$ is lower than the human guideline of 0.4 to $1.0 \mathrm{ppm}$, it is therefore possible that regulations established to protect the most vulnerable wildlife also will afford protection for humans. Because the challenge in protecting human and wildlife health from mercury poisoning is exactly the same-understanding toxic thresholds and then keeping mercury in diets below harmful thresholds-more interaction and cooperation between wildlife and human toxicologists would be desirable. 


\section{How Embryotoxic Thresholds of Mercury Can Be Estimated from Mercury Levels in Individual Eggs}

\author{
By Gary H. Heinz ${ }^{1}$ and David J. Hoffman ${ }^{2}$
}

${ }^{1}$ U.S. Geological Survey, Patuxent Wildlife Research Center, Beltsville, MD (gary_heinz@usgs.gov)

${ }^{2}$ U.S. Geological Survey, Patuxent Wildlife Research Center, Beltsville, MD (david_hoffman@usgs.gov)

The results from controlled laboratory studies with mallards (Anas platyrhynchos) have been used to help establish the concentrations of mercury in avian eggs that are associated with harmful effects on reproduction. In these earlier lab studies, groups of breeding adult mallards were fed different concentrations of methylmercury and a mean mercury level was calculated from a sample of eggs from each group. As contrasted to this earlier, group-mean approach, our objective in the current study was to use mercury concentrations in individual mallard eggs to estimate the lowest concentrations of mercury in eggs that would harm the most sensitive embryos. In addition, we wanted to determine how much mercury the most mercury-tolerant embryos could be exposed to and still hatch normally and survive. To make these measurements we needed a way to estimate the mercury level in an egg while still allowing that egg to go through incubation, hatching, and chick survival. We made this estimate of mercury in incubated eggs by allowing the even-numbered eggs to go through incubation, while saving the odd-numbered eggs for mercury analysis. To estimate the concentration of mercury in the even-numbered eggs, we used the average of what was in the neighboring odd-numbered eggs.

Pairs of mallards were first fed an uncontaminated diet, were then switched to a diet containing 5,10 , or $20 \mu \mathrm{g} / \mathrm{g}$ mercury as methylmercury, and were later returned to the uncontaminated diet. Eggs were incubated throughout the pre-treatment, uptake, and loss phases of the experiment. Neurological signs of methylmercury poisoning were observed in ducklings that hatched from eggs that were estimated to contain as little as $2.3 \mu \mathrm{g} / \mathrm{g}$ estimated mercury on a wet-weight basis, and deformities were seen in embryos from eggs containing about $1 \mu \mathrm{g} / \mathrm{g}$ estimated mercury. Although embryo mortality was seen in eggs estimated to contain as little as $0.74 \mu \mathrm{g} / \mathrm{g}$ mercury, there were considerable differences in the sensitivity of mallard embryos, especially from different parents, with some embryos surviving as much as 30 or more $\mu \mathrm{g} / \mathrm{g}$ mercury in the egg. It seems that only a very small percentage of mallard embryos are likely to be harmed by mercury concentrations of $1 \mu \mathrm{g} / \mathrm{g}$ or less in eggs on a wet-weight basis. Results from this study provide the most reliable and rigorous data to date on the minimum concentrations of mercury in eggs that cause harm to the most sensitive avian embryos.

\section{Mercury Accumulation and Loss in Mallard Eggs}

By Gary H. Heinz' and David J. Hoffman²

${ }^{1}$ U.S. Geological Survey, Patuxent Wildlife Research Center, Beltsville, MD (gary_heinz@usgs.gov)

${ }^{2}$ U.S. Geological Survey, Patuxent Wildlife Research Center, Beltsville, MD (david_hoffman@usgs.gov)

The movement of methylmercury through food chains and ultimately into the eggs of aquatic birds is suspected as a cause of reduced reproductive success. Controlled laboratory studies have been used to estimate the concentrations of mercury in eggs that are associated with impaired hatching success and survival of young, but in these controlled studies the females were fed a constant diet containing methylmercury, whereas in nature breeding birds may move into or out of mercury-contaminated areas at the time when they begin laying eggs. Therefore, it is important to learn how quickly mercury can accumulate and decline in eggs once it is introduced into or removed from the diet of the parent.

We used a lab study with mallards (Anas platyrhynchos) to study mercury accumulation and loss, as measured by mercury concentrations in a series of eggs. Female mallards were fed diets containing 5, 10, or 20 ppm mercury as methylmercury chloride. One egg was collected from each bird prior to the start of the mercury diets and 15 eggs were collected from each bird while it was being fed mercury. The mercury diets were then replaced by uncontaminated diets, and each female was allowed to lay 29 more eggs. Our study showed that if a female bird began feeding in an area heavily contaminated with mercury, it would only take a few days for mercury levels in eggs to reach those that would harm the most sensitive embryos (currently believed to be about 1 ppm on a wetweight basis). Mercury levels in eggs rose to about 7, 18, and 35 ppm, wet-weight, in females fed 5, 10, or 20 ppm mercury, respectively. In the reverse situation, where a female bird was feeding in a heavily contaminated area but then moved to an uncontaminated area at the time she began egg laying, mercury concentrations in eggs would immediately begin to decline. However, depending upon the amount of mercury stored in her body at the time she began egg laying, she might still deposit harmful levels of mercury into her eggs for anywhere from a few days to several weeks. Mercury levels fell to about 0.16 , 0.80 , and $1.7 \mathrm{ppm}$ in the last egg laid by birds that had earlier been fed 5, 10, or 20 ppm mercury, respectively.

Higher concentrations of mercury were found in egg albumen than in yolk, and between 95 and 100 percent of the mercury in the eggs was in the form of methylmercury. The practical application of our work relates to a better understanding of the possible harm mercury may pose to the reproduction of birds moving into or out of mercury-contaminated areas at about the time they begin egg laying. 
Enhancement of WARMF to Track Mercury Species in a
River Basin from Atmospheric Deposition to Fish Tissue

By Carl W. Chen', Joel W. Herr², Robert A. Goldstein ${ }^{3}$, and

Keith Hanson ${ }^{4}$

${ }^{1}$ Systech Engineering, Inc., San Ramon, CA

(carl@systechengineering.com)

${ }^{2}$ Systech Engineering, Inc., San Ramon, CA (joel@systechengineering.com)

33ectric Power Research Institute, Palo Alto, CA (rogoldst@epri.com)

${ }^{4}$ Minnesota Power Company; Duluth, MN (khanson@mnpower.com)

A GIS-based watershed model (WARMF) was enhanced to track mercury species from atmospheric deposition through watershed compartments to fish tissue. The enhancements include new equations to account for (1) canopy processes that accept wet and dry depositions of $\mathrm{MeHg}$ and $\mathrm{Hg}$ (II); (2) litter fall that contains $\mathrm{MeHg}$ and $\mathrm{Hg}$ (II) through foliar uptake; (3) photo reduction and evasion of $\mathrm{Hg}(0)$ in un-shaded areas of catchments; (4) transport of $\mathrm{MeHg}$ and $\mathrm{Hg}$ (II) together with suspended sediment and DOC from lands to surface waters; (5) photo reduction and evasion of $\mathrm{Hg}(0)$ at lake surface; (6) methylation of $\mathrm{Hg}$ (II) to $\mathrm{MeHg}$ at bottom sediments of wetlands and lakes by sulfate reducing bacteria; (7) diffusions of sulfate and hydrogen sulfide between sediment and lake water; and (8) bioaccumulation of $\mathrm{MeHg}$ through the food web. Such enhancements enable WARMF to calculate mercury TMDL using fish-tissue mercury concentration as the endpoint. The model formulations and preliminary results were peer reviewed by a panel of experts, organized by Dr. Diane Desotelle of Minnesota Sea Grant Program and chaired by Dr. Charles Driscoll of Syracuse University.

The enhanced WARMF was applied to the St. Louis, Nemadji, and North Coast Rivers of Minnesota that drain to Lake Superior. Preliminary results show that WARMF simulated hydrology and concentrations of mercury species in various river sections that were comparable to the observed data. Predicted fish-tissue concentrations of methylmercury were in the range of scattered data. The new atmospheric deposition and legacy mercury accumulated in soil contribute nonpoint source mercury to rivers and lakes. Uncertainty analysis with Jackknife simulation shows that methylation rate controls the model prediction more than adsorption coefficient $(\mathrm{Kd})$ or concentration of legacy mercury (Co). A 30-percent reduction of atmospheric deposition may lower mercury concentrations in rivers and in fish tissue of the St. Louis River Basin very slowly.
Distribution of Mercury in Shallow Ground Water of the New Jersey Coastal Plain and a Possible Mechanism of Transport

By Julia L. Barringer ${ }^{1}$ and Zoltan Szabo ${ }^{2}$

${ }^{1}$ U.S. Geological Survey, West Trenton, NJ (jbarring@usgs.gov)

${ }^{2}$ U.S. Geological Survey, West Trenton, NJ (zszabo@usgs.gov)

More than 400 domestic wells that tap the major unconfined aquifer in 72 areas in New Jersey's Coastal Plain have yielded water containing total mercury at concentrations exceeding the maximum contaminant level (MCL) of $2 \mu \mathrm{g} / \mathrm{L}$. Concentrations of mercury in the aquifer typically are less than $0.01 \mu \mathrm{g} / \mathrm{L}$. Additional water-quality data collected at several of these contaminated areas indicate that concentrations of chloride and nitrate also are elevated.

In a regional study conducted by the U.S. Geological Survey in cooperation with the New Jersey Department of Environmental Protection, 126 domestic and observation wells in different land-use areas and 28 clustered observation wells in undeveloped and agricultural land were sampled. Mercury concentrations typically were less than $0.01 \mu \mathrm{g} / \mathrm{L}$ in filtered (0.45- $\mu \mathrm{m}$ pore size) samples, but tended to increase with concentrations of chloride (and other constituents), indicating that mercury may be transported as a chloride complex. Concentrations of mercury $>0.1 \mu \mathrm{g} / \mathrm{L}$ did not correlate with concentrations of other constituents, however, indicating that mercury near and at the MCL may not be transported in the same chemical form as mercury at lower concentrations. Mercury concentrations $>1 \mu \mathrm{g} / \mathrm{L}$ typically are associated with residential land use, but such high concentrations have not been found in water underlying undeveloped land. The distribution of these elevated mercury concentrations appears to be "spotty" at both the regional and neighborhood scales, as the presence of extensive plumes of mercury-contaminated ground water could not be demonstrated.

In a related study of 31 observation and domestic wells in one residential area, 14 domestic wells yielding mercurycontaminated water were resampled; mercury concentrations in filtered samples were much smaller $(<0.1$ to $3.1 \mu \mathrm{g} / \mathrm{L})$ than those in previously collected unfiltered samples $(2.0$ to $15 \mu \mathrm{g} / \mathrm{L})$, indicating that much of the mercury present is adsorbed to particulate and colloidal material. Mercury concentrations were lower and mercury commonly was more evenly distributed in the soil profile of residential soils than in adjacent undisturbed forest soils in the area. The depletion of mercury in the residential soils likely indicates that mercury has been mobilized and transported from these soils to ground water. Detections of surfactants, ammonia, and sulfide, and high sodium and chloride concentrations (up to 59 and $89 \mathrm{mg} / \mathrm{L}$, respectively) in water from many of the 31 wells likely indicate that septic-system effluent has affected water quality; this may provide a geochemical environment conducive to mercury mobilization. 
On the basis of results from these studies, a four-part hypothesis is advanced regarding mercury transport in shallow ground water. (1) Mercury has been contributed to soils by atmospheric deposition and historical use of mercurial pesticides. (2) Mercury is mobilized from soils by disturbance during development activities. (3) Septic-system effluent provides sulfur-rich organic matter to bind mercury to organic colloids or particles and surfactants to promote colloid mobility.
(4) Periodic surges in well pumping increase interstitial porewater velocity, enhancing mobility and capture of colloids by wells. This preliminary model may be applicable throughout much of southern New Jersey, as other residential areas with mercury-contaminated ground water typically are unsewered housing developments. A research program to evaluate this hypothesis is under development. 


